ROCZNIKI HISTORYCZNE

Rocznik LXXXI - 2015

\author{
MATEUSZ KOSONOWSKI (Kraków)
}

\title{
Legacja Gwalona z Beauvais w Polsce w 1103 roku*
}

\section{WSTĘP}

Działalność legatów Stolicy Apostolskiej w dobie tzw. dojrzałego średniowiecza przyciąga uwagę historiografii zachodnioeuropejskiej od przeszło wieku¹. Również w polskiej mediewistyce zgłębianie tej problematyki ma długą tradycję, badania jednak ogniskują się przeważnie na relacji państwa i Kościoła polskiego z papiestwem między X a XIII w. ${ }^{2}$ Jednym z zagadnień, które wciąż wzbudza ożywioną dyskusję, jest wizyta w Polsce legata Gwalona, biskupa elekta Beauvais, a później ordynariusza

* Autor pragnie złożyć serdeczne podziękowania Dyrekcji i Pracownikom Biblioteki Niemieckiego Instytutu Historycznego w Rzymie, którym zawdzięcza dostęp do zagranicznej literatury i wydawnictw źródłowych. Wyrazy wdzięczności kieruję też w stronę moich Mistrzów, Panów Profesorów Krzysztofa Ożoga, Stanisława A. Sroki oraz Marka D. Kowalskiego, jako pierwszych krytycznych, ale i życzliwych czytelników niniejszego tekstu.

${ }^{1} \mathrm{Z}$ nowszej literatury zob. np. R. H i e s t a n d, Les légats pontificaux en France du milieu $\mathrm{XI}^{\mathrm{e}}$ à la fin du XII ${ }^{\mathrm{e}}$ siècle, w: L'Église de France et la papauté $\left(\mathrm{X}^{\mathrm{e}}-\mathrm{XIII}{ }^{\mathrm{e}}\right.$ siècle). Die französische Kirche und das Papsttum (10.-13. Jahrhundert), Paris 1993, s. 54-80; Ch. Schuchard, Päpstliche Legaten und Kollektoren nördlich der Alpen, w: Kommunikation und Möbilitat im Mittelalter. Begegnungen zwischen dem Süden und der Mitte Europas (11. bis 14. Jahrhundert), Sigmaringen 1995, s. 261-269; C. Z e y, Handlungsspielräume - Handlungsinitiativen. Aspekte der päpstlichen Legatenpolitik im 12. Jahrhundert, w: Zentrum und Netzwerk. Kirchliche Kommunikation und Raumstrukturen im Mittelalter, Berlin 2008, s. 63-92; ostatnio t a ż, M. P. A 1 berzoni, Legati papali e delegati papali (secoli XII-XIII). Stato della ricerca e questioni aperte, w: Legati e delegati papali. Profili, ambiti d'azione e tipologie di intervento nei secoli XII-XIII, Milano 2012, s. 3-12.

${ }^{2}$ Wciąż nie dysponujemy monograficznym ujęciem stosunków Polski piastowskiej z papiestwem, choć ważnym krokiem na tej drodze jest publikacja tomu Polonia Pontificia, sive repertorium privilegiorum et litterarum a Romanis pontificis ante annum MCLXXXXVIII Poloniae... concessorum, opr. W. Könighaus, Gottingae 2014. Z ostatnich publikacji por. też J. D o b o s z, Monarcha i możni wobec Kościoła w Polsce do początku XIII wieku, Poznań 2002, zwł. s. 61-79, 171-175, 202-220, 222-226, 421-423, 433-439; K. S k w i e r c z y ń s k i, Recepcja idei gregoriańskich w Polsce do początku XIII wieku, Wrocław 2005, zwł. s. 42-57, 147-190, 260-316; W. B a r a n - K o zł o w s k i, Arcybiskup gnieźnieński Henryk Kietlicz (1199-1219), Poznań 2005, zwł. s. 43-51, 94-119, 204-213; P. N o w a k, Die polnische Kirchenprovinz Gnesen und die Kurie im 12. Jahrhundert, w: Römisches Zentrum und kirchliche Peripherie. Das universale Papsttum als Bezugspunkt der Kirchen von den Reformpäpsten bis zu Innocenz III., Berlin 2008, s. 191-206; t e n ż e, Das Papsttum und Ostmitteleuropa (Böhmen-Mähren, Polen, Ungarn) vom ausgehenden 10. bis zum Beginn 13. Jahrhunderts, 
paryskiego, który przybył nad Wisłę na początku XII w. ${ }^{3}$ Mimo upływu lat i stale powiększającego się zasobu studiów o tym wydarzeniu, dalecy jesteśmy od zgodnej odpowiedzi nawet na fundamentalne pytania. Winne temu, rzecz jasna, niezwykle lapidarne i enigmatyczne przekazy źródłowe, spośród których na czołowe miejsce wysuwa się świadectwo Galla Anonima, którego narracja nie tylko powstała bardzo krótko po opisywanych wydarzeniach, ale jest też najobszerniejsza. Przytoczmy ją w całości: Eo [Boleslao] itaque de Morauia satis glorianter redeunte Romane sedis legatus Walo nomine, Beluacensis episcopus, Poloniam advenit, qui cum virtute Bolezlaui, zelo iustitie tantum canonum districcionis rigorem exercuit, quod duos episcopos ibi nullo vel prece vel pretio subveniente deposuit. Sedis itaque Romane legato reverenter honorato, concilioque canonice celebrato, missus apostolica data benedictione, Romam rediit, beliger vero Bolezlauus hostes suos impugnaturus adiit ${ }^{4}$. W ślad za Gallem niemalże identycznymi słowami opisał ten fakt autor czternastowiecznej Kroniki książąt polskich, który nie wnosi jednak żadnych nowych informacji5 . Chronologię określają nam zapiski kilku polskich roczników, wywodzące się, jak powszechnie wiadomo, z tzw. Annales Regni Polonorum deperditi. Poza datacją nie dowiadujemy się z nich wszakże niczego nowego ${ }^{6}$.

W konsekwencji zasób pewnych wiadomości, jakimi dysponujemy, ogranicza się do następujących faktów: a) po wyprawie Bolesława Krzywoustego na Morawy

w: Rom und die Regionen. Studien zur Homogenisierung der lateinischen Kirche im Hochmittelalter, Berlin 2012, s. 331-370.

3 Zestawienie wszelkich wzmianek w źródłach francuskich o Gwalonie sporządził A. L u c h a ir e, Louis VI le Gros. Annales de sa vie et de son règne (1081-1137), Paris 1890, s. 10 (nr 17), s. 18 (nr 29), s. 25 (nr 46), s. 26 (nr 49), s. 30-32 (nr 56-58), s. 58 n. (nr 109), s. 69 n. (nr 131), s. 82 (nr 160), s. 87 n. (nr 172), s. 91 n. (nr 178), s. 95 (nr 188), s. 96 n. (nr 192), s. 106 n. (nr 218), s. 247 (nr 540). Zob. też B. Mo n o d, L'Eglise et l'Etat au XII ${ }^{e}$ siècle. L'élection épiscopale de Beauvais de 1100 à 1104. Etienne de Garlande et Galon, Mémoires de la Société Académique d'Archéologie du Département de l'Oise 19, 1904/1906, s. 53-74, zwł. s. 61-67; t e n ż e, Essai sur les rapports de Pascal II avec Philippe I ${ }^{\text {er: }}$ 10991118, Paris 1907, zwł. s. 27-34, 41 n., 72-80, 108 n., 116 n.; P. D a v i d, Un disciple d'Yves de Chartres en Pologne - Galon de Paris et le droit canonique, w: La Pologne au VII ${ }^{\text {e Congrés }}$ International des scientes historiques, t. I, Varsovie 1933, zwł. s. 99-109; C. R o 1 k e r, Canon Law and the Letters of Ivo of Chartres, Cambridge 2009, zwł. s. 9, 16, 242, 265.

${ }^{4}$ Galli Anonymi Cronicae et gesta ducum sive prinicipum Polonorum, II 27, wyd. K. Maleczyński, Monumenta Poloniae historica (dalej cyt.: MPH), series nova (dalej cyt.: SN), t. II, Cracoviae 1952, s. 94; thum. pol.: Anonim tzw. Gall, Kronika polska, thum. R. Grodecki, opr. M. Plezia, Wrocław 2003, s. 91 n. Warto zauważyć, że istnieje istotna różnica w thumaczeniu frazy: quod duos episcopos ibi nullo vel prece vel pretio subveniente deposuit. R. Grodecki tłumaczył: ,że dwóch biskupów złożył z godności, przy czem nie pomogła ani prośba żadna, ani zapłata" (Anonim tzw. Gall, Kronika polska, Kraków 1923, s. 123), natomiast M. Plezia proponuje tłumaczenie: „że na miejscu złożył z godności dwóch biskupów, za którymi nikt się [zresztą] nie ujął prośbą ani zapłatą" (wyd. z 2003 r., s. 92).

${ }^{5}$ Zob. Kronika książąt polskich, wyd. Z. Węclowski, MPH III, Lwów 1878, s. 458.

${ }^{6}$ Rocznik kapituły krakowskiej, wyd. Z. Kozłowska-Budkowa, MPH SN V, Warszawa 1978, s. 54 (1104: Gualo episcopus Beluacensis sedis apostolice legatus intrat Poloniam Urbano II sedi apostolice presidente, et duos episcopos deponit); por. też Rocznik małopolski, wyd. A. Bielowski, MPH III, s. 150 n. (w redakcjach z kodeksów Kuropatnickiego i lubińskiego pod 1103 oraz królewieckiego pod 1105); Rocznik Sędziwoja, wyd. A. Bielowski, MPH II, Lwów 1872, s. 874 (pod 1103). 
przybył do Polski legat Gwalo, który b) otrzymał wsparcie od księcia w podjętej misji, dzięki czemu c) udało mu się zwołać synod, na którym d) złożył z urzędu dwóch anonimowych polskich biskupów, ale e) nikt się za nimi nie ujął, po czym legat f) udzielił błogosławieństwa i g) odjechał z powrotem do Wiecznego Miasta. Mimo długiej i polifonicznej dyskusji bez wyczerpującej odpowiedzi pozostało natomiast kilka kluczowych pytań: 1) którą z obecnych w źródłach datę legacji uznać za poprawną (1103, 1104 czy 1105)?, 2) którzy biskupi zostali usunięci?, 3) jakie mogły być najbardziej prawdopodobne powody tych działań legata w świetle pryncypiów polityki papieskiej na początku pontyfikatu Paschalisa II? oraz 4) czy zasadne jest powszechne w literaturze przekonanie, iż legat przywiózł ze sobą do Polski egzemplarz tzw. Tripartity, który potem dwukrotnie skopiowano na miejscu? Problemy te rozważymy poniżej według zaznaczonej kolejności.

\section{DATACJA WIZYTY GWALONA W POLSCE}

Jak zauważyliśmy, chcąc ustalić datę pobytu legata w państwie Bolesława Krzywoustego, musimy rozważyć trzy możliwości: 1103, 1104 lub 1105 r. ${ }^{7}$ Niektórzy badacze sugerowali też przygodnie, aby spróbować uzgodnić ze sobą argumenty przemawiające za 1104 i 1105 r. , jednak zabiegi te okazały się nieprzekonujące, toteż bez uszczerbku dla wywodu możemy tę propozycję pominąć. Z pełnym przekonaniem możemy też odrzucić rok 1105. Upoważnia do tego jednoznaczne świadectwo źródeł francuskich, a konkretnie akta synodu w Paryżu z 9 XII 1104 r., gdzie wśród zebranych figuruje też Gwalo ordynariusz paryski . Ponieważ w Polsce legat występuje jeszcze jako biskup Beauvais, jego misja legacka musiała przypaść na okres przed grudniem $1104 \mathrm{r}$.

Ważną wskazówką, umożliwiającą bardziej precyzyjne datowanie legacji, byłaby dokładna data objęcia przez Gwalona tronu biskupiego w Paryżu. Ta jednak nie została zapisana w żadnym ze współczesnych źródeł, a późniejsza wzmianka o jego ordynacji

${ }^{7}$ Wyczerpujące zestawienie dotychczasowych głosów w dyskusji dał ostatnio P. N o w a k, Legacja Galona, biskupa-elekta Beauvais do Polski w 1104 roku i Collectio tripartita, Przegląd Historyczny 105, 2014, s. 425-433, tu s. 428, sam opowiadając się za 1104 r.; por. też M. K o s o n ow s ki, Postać i panowanie Bolesława Krzywoustego w nowym historiograficznym ujęciu. Kilka uwag o pracy Stanisława Rosika „Bolesław Krzywousty”, Studia Historyczne 57, 2014, s. 249-255.

${ }^{8}$ Np. ks. J. K o ry t k o w s k i, Arcybiskupi gnieźnieńscy, prymasowie Polski i metropolici polscy od roku 1000 aż do roku 1821, t. I, Poznań 1888, s. 213-215; G. L a b u d a, Dyplomacja polska wczesnego feudalizmu (wiek X - 1306 r.), w: Historia dyplomacji polskiej, t. I, Warszawa 1982, s. 121, 130; W. S w o b o d a, Papiestwo a Słowianie, w: Słownik starożytności słowiańskich, t. VIII, Wrocław 1991, s. 500.

9 Papsturkunden in Frankreich (Neue Folge), wyd. J. Ramackers, t. III: Artois, Göttingen 1940, nr 9, s. 45 n.: Conuenientes itaque Parisius tum ex apostolica auctoritate, tum ex regia inuitatione archiepiscopi, dominus uidelicet Daimbertus Senonensis, Radulfus Turonensis, episcopi quoque Iuo Carnotensis - - Gualo Parisiensis - -. Actum Parisius anno Dei Christi MCIIII, Vidus Decembris, indictione XII, anno pontificatus Paschalis II V. Precyzyjność tej daty nie może ulegać wątpliwości. Dawne wydanie błędnie wiązało to zgromadzenie z $1105 \mathrm{r}$. (J. D. M a n s i, Sacrorum concilliorum nova et amplissima collectio, t. XX, Venetiis 1775, kol. 1193). 
pod $1103 \mathrm{r}$. w kronice Alberyka z Trois-Fontaines ${ }^{10}$ nie wytrzymuje konfrontacji z bardziej wiarygodną korespondencją Iwona z Chartres. Wystarczy przywołać niezwykle ważny, choć niedatowany, list Iwona, w którym informuje on papieża Paschalisa II, że w miejscowości Beaugency odbył się synod, któremu przewodniczył legat Stolicy Apostolskiej, kardynał Ryszard z Albano ${ }^{11}$. Dla nas kluczowe jest tu zdanie: $D e$ caetero Sanctae Paternitati vestrae supplicando suggerimus, ut domnum Gualonem coepiscopum nostrum, de Belvacensi episcopatu, quam propter sacramentum domni Ludovici habere non potest, per manum Senonensis archiepiscopi transferri iubeatis in Parisiensem episcopatum, quam ei gratanter et devote concedunt pro vestro amore Rex et Regis filius. Biorąc pod uwagę, że synod obradował pod koniec lipca 1104 r., a poprzednik Gwalona na biskupstwie paryskim, Fulko, umarł 8 kwietnia tego roku $^{12}$, logiczne wydaje się, że rozmowy o objęciu przez tego pierwszego rządów nad diecezją musiały się toczyć co najmniej od kwietnia 1104 r. aż do finału w Beaugency ${ }^{13}$. Skoro zaś na grudniowym synodzie w Paryżu Gwalo tytułowany jest już biskupem paryskim, winniśmy uznać, że musiał on objąć tę diecezję między 30 VII a 9 XII 1104 r. Niewykluczone jednak, że zwolennicy Gwalona rozpoczęli zabiegi o tę godność dla niego na przyszłość jeszcze przed śmiercią Fulka. Król był pierwotnie nieprzychylnie ustosunkowany do kandydata, skutecznie uniemożliwiając mu przedtem objęcie biskupstwa w Beauvais, na które został wybrany przez część tamtejszej kapituły jako konkurent przychylnego Ludwikowi VI Stefana Garlanda ${ }^{14}$. Czy sam zainteresowany brał udział $\mathrm{w}$ tych rokowaniach? Na to pytanie nie ma niestety odpowiedzi, ale nie możemy z góry wykluczyć takiej możliwości. Osobistemu udziałowi Gwalona przynajmniej w początkowej fazie rokowań na pierwszy rzut oka zdają się zaprzeczać wyniki ostatnich studiów Przemysława Nowaka, który

${ }^{10}$ Chronica Alberici monachi Trium Fontium, wyd. P. Scheffer-Boichorst, Monumenta Germaniae historica (dalej cyt.: MGH), Scriptores, t. XXIII, Hannoverae 1874, s. 815 (1103: Gualo Belvacensis episcopus translatus est ad episcopatum Parisiensem).

${ }^{11}$ Epistolae Ivonis Carnotensis episcopi, wyd. M. J. Brial, w: Recueil des historiens des Gaules et de la France, t. XV, Paris 1878, nr 89, s. 129: Notum facimus Paternitati vestrae, quod III kal. Augusti plures episcopi tam Remensis, quam Senonensis provinciae, invitati a domno Richardo Albanensi episcopo legato vestro, convenimus in quondam municipum Aurelianensis episcopatus, nomine Balgenciacum. Wprawdzie Iwo podaje tylko datę dzienną (30 VII), jednak w połączeniu z innymi źródłami mówiącymi o legacji Ryszarda we Francji wiemy, że synod obradował w 1104 r. (T. S c h i e ffe r, Die päpstlichen Legaten in Frankreich vom Vertrage von Meersen (870) bis zum Schisma von 1130, Berlin 1935, s. 169-175, zwł. s. 173175; R. H ü 1 s, Kardinäle, Klerus und Kirchen Roms 1049-1130, Tübingen 1977, s. 93-95; S. We i $ß$, Die Urkunden der päpstlichen Legaten von Leo IX. bis Coelestin III. (1049-1198), Köln 1995, s. 45 n.).

${ }^{12}$ Obituaire de la cathédrale Notre-Dame de Paris, wyd. A. Molinier, w: Obituaires de la province de Sens, t. I: Dioèceses de Sens et de Paris, Paris 1902, s. 117 (pod 8 IV: De domo Sancte Marie, obiit Albertus sacerdos, atque Fulco, Parisiensis ecclesie episcopus [1104]). Wpisu dokonano trzynastowieczną ręką, a kolejny biskup Fulko występuje dopiero w XIV w., chodzi tu zatem na pewno o poprzednika Gwalona.

${ }^{13}$ A. L u c h a ir e, Louis VI, nr 29; zob. też J. D e p o i n, Essai sur la chronologie des évêques de Paris de 768 à 1138, Bulletin historique et philologique du Comité des travaux historiques et scientifiques 24, 1906, s. 238; C. R o 1 k e r, Canon Law, s. 242 n.

14 Szczegóły tego sporu omawia dokładnie B. M o n o d, L’Eglise et l’Etat, s. 61-74. 
idąc śladem rozumowania Rolfa Sprandela, uważa, że w pierwszych miesiącach 1104 r. Gwalo znajdował się w drodze do Polski ${ }^{15}$. Asumpt do takiej hipotezy stanowi dla obydwu badaczy relacja o spotkaniu Gwalona ze św. Anzelmem z Canterbury w Lyonie, którą umieścił mnich Eadmer w swoim Żywocie św. Anzelma ${ }^{16}$. Miałoby z niej wynikać, że do spotkania doszło najpóźniej w marcu 1104 r., wówczas bowiem Anzelm miałby opuścić Lyon. Sprawa nie jest jednak tak prosta, ponieważ: a) zarówno P. Nowak, jak i R. Sprandel korzystają z przestarzałej edycji Żywotu św. Anzelma ${ }^{17}$, na podstawie której błędnie umieścili to wydarzenie pod 1104 r. (w tekście data roczna ani miesięczna nie pada), b) składnia kluczowego zdania łacińskiego nie pozwala przesądzić, czy piastowanie przez Gwalona godności legata Stolicy Apostolskiej było przeszłością z punktu widzenia interlokutorów, czy też dopiero z punktu widzenia autora żywotu $^{18}$. Wydaje się zatem, że racja jest po stronie Richarda W. Southerna, który prześledziwszy dokładnie itinerarium Anzelma w pierwszej dekadzie XII w., sugeruje, że do spotkania doszło dopiero w trakcie podróży powrotnej Gwalona z Rzymu do Francji, bezpośrednio po uzyskaniu przezeń konsekracji papieskiej po wyborze na biskupa paryskiego, mniej więcej w kwietniu-maju 1105 r. ${ }^{19}$ Wobec tego zaś przekaz Eadmera nie ma dla nas rozstrzygającego znaczenia, jedyne bowiem niepodważalne wiadomości, jakie daje się z niego wyprowadzić, potwierdzają tylko, że Gwalo był legatem papieskim (nazwa kraju nie pada) i przejeżdżając przez Lyon, spotkał się z Anzelmem. Nie wyklucza to, że przez pierwszą połowę 1104 r. biskup elekt Beauvais mógł bawić we Francji.

Źródłom francuskim trzeba jeszcze zadać pytanie, od kiedy Gwalo mógł posługiwać się tytulaturą biskupa Beauvais, której, jak wiemy, używał w Polsce. Na właściwy trop zdaje się wprowadzać nas kolejny list Iwona z Chartres, w którym relacjonuje on po raz pierwszy papieżowi, że na rządcę diecezji Beauvais wybrano

${ }_{15}$ P. N ow a k, Legacja Galona, s. 429; t e n ż e, Die polnische Kirchenprovinz, s. 194198; por. R. S prande 1, Ivo von Chartres und seine Stellung in der Kirchengeschichte, Stuttgart 1962, s. 190.

${ }^{16}$ Eadmeri monachi Cantuariensis Vita sancti Anselmi archiepiscopi Cantuariensis (The Life of St Anselm by Eadmer), II 55, wyd. R. W. Southern, London 1962, s. 132 n.

17 Vita sancti Anselmi auctore Eadmero, w: Patrologiae Latinae cursus completus, t. 158, Parisiis 1863, kol. 111; por. też kol. 134.

${ }^{18}$ Eadmeri Vita sancti Anselmi, s. 132: Venit ad nos Walo, episcopus Parisiacensis, vir bene religiosus et ecclesiasticarum consuetudinum institutionibus ab ineunte aetate imbutus. Hic Romae notus et apostolicae legationis ministerio functus, familiaritatis patris Anselmi potiebatur.

19 R. W. S o u th e rn, Saint Anselm and his Biographer. A Study of Monastic Life and Thought 1059 - ca. 1130, Cambridge 1963, s. 162-164, 173-176 (gdzie o dwóch pobytach Anzelma w Lyonie); por. też Eadmeri Vita sancti Anselmi, s. 132-135. Szczegóły chronologiczne w świetle korespondencji Anzelma ustalił też ostatnio R. Z i n g g, Die Briefsammlungen der Erzbischöfe von Canterbury 1070-1170. Kommunikation und Argumentation im Zeitalter der Investiturkonflikte, Köln 2012, s. 119-129, 165-171, 193-194. O tym, że Gwalo udał się po konsekrację do Rzymu i był tam obecny do kwietnia 1105 r., zaświadcza list Paschalisa II (Epistolae Paschalis II papae, wyd. M. J. Brial, w: Recueil des historiens des Gaules, t. XV, nr 30, s. 28 n.). Wprawdzie w tekście nie pada data roczna (jedynie Datum Laterani, VIII idus Aprilis), jednak korespondencja dotyczy zatwierdzenia wyboru na biskupa Paryża, którą to datę ustaliśmy powyżej na 30 VII - 9 XII 1104 r. 
Stefana Garlanda ${ }^{20}$. Źródło to nie jest wprawdzie opatrzone datą, ale, jak słusznie zauważono $^{21}$, powstało bezpośrednio po innym liście Iwona ${ }^{22}$, napisanym podczas pobytu we Francji legatów papieskich Jana kardynała św. Anastazji oraz Benedykta kardynała św. Prudencji, a zatem w ostatnich miesiącach $1100 \mathrm{r}^{23}$ Mniej więcej w tym okresie, zapewne w drugiej połowie 1100 r., część kanoników kapituły w Beauvais dokonała elekcji Stefana, prosząc niezwłocznie Iwona, aby udzielił elektowi sakry, o czym donosi on nie bez zażenowania w jednym z kolejnych listów Paschalisowi ${ }^{24}$. Odmawiając Garlandowi odpowiednich kompetencji do sprawowania rządów nad diecezją $a^{25}$, Iwo rozpoczął szeroko zakrojoną akcję pozyskiwania stronników dla własnego kandydata, Gwalona, akcentując często jego gruntowne wykształcenie i wysokie kwalifikacje moralne ${ }^{26}$. Zabiegi te okazały się owocne do tego stopnia, że w dwóch kolejnych listach do papieża Iwo mógł już obwieścić, że Gwalo został wybrany. Nie wiemy niestety dokładnie, kiedy korespondencja ta powstała, ale w literaturze występuje dość zgodnie opinia, że wybór nastąpił przed 1102 r. Jedyną przesłanką, nieśmiało sugerującą słuszność tak określonego terminu ante quem, jest miejsce, jakie zajmują owe listy do Paschalisa w obrębie całości korespondencji Iwona z pierwszych lat XII w., wpisując się tonem i przekazywanymi wiadomościami $\mathrm{w}$ ciąg listów $\mathrm{z}$ lat $1100-1102^{27}$.

Z analizy źródeł francuskich otrzymujemy zatem trzy ważne ustalenia: a) legacja Gwalona musiała mieć miejsce przed 1105 r., o czym świadczą akta synodu w Paryżu z 1104 r.; b) nie da się wykazać na gruncie Żywotu św. Anzelma, że Gwalo przed marcem 1104 r. spotkał się w Lyonie z Anzelmem; c) zarówno w 1103, jak i w 1104 r. legat Stolicy Apostolskiej mógł tytułować się biskupem Beauvais.

Bogatsi o te wnioski możemy zastanowić się, co na temat okoliczności wizyty Gwalona w Polsce oraz wydarzeń bezpośrednio ją poprzedzających mają do powiedzenia źródła powstałe w Polsce i krajach ościennych. Punktem wyjścia będzie dla nas początek cytowanej już wyżej relacji Galla Anonima, w której mowa jest, że przed przybyciem wysłannika papieskiego Bolesław Krzywousty wyprawił się na

${ }^{20}$ Epistolae Ivonis, nr 55, s. 109 n.

${ }^{21}$ Np. A. F 1 i c h é, Le règne de Philippe Ire, roi de France (1060-1108), Paris 1912, s. 441;

R. S prande 1, Ivo von Chartres, s. 189.

${ }^{22}$ Epistolae Ivonis, nr 54, s. 109.

${ }^{23}$ T. S c h i e ff e r, Die päpstlichen Legaten, s. 163-169; S. B e u l e r t z, Das Verbot der Laieninvestitur im Investiturstreit, Hannover 1991 (MGH Studien und Texte 2), s. 15, 129 n.; S. We i $\beta$, Die Urkunden, s. 38-41.

${ }^{24}$ Epistolae Ivonis, nr 57, s. 111.

25 Tamże, nr 60, s. 113 (do biskupów Lamberta z Arras oraz Jana z Thérouanne); nr 61, s. 114 (do kapituły w Beauvais).

${ }^{26}$ Dodatkowym powodem wspierania przez Iwona kandydatury Gwalona był fakt, że był on jego wychowankiem (Epistolae Ivonis, nr 54: praedictus electus [Gwalo] discipulus meus fuerat, apud me nutritus, apud me eruditus). Z rąk Iwona przejął też Gwalo rządy nad wspólnotą kanoników regularnych Saint Quentin w Beauvais ok. 1090/1091 r. Szerzej zob. P. D a v i d, Un disciple, s. 99-109; C. D u m o n t, L'abbaye de Saint-Quentin de Beauvais (XI ${ }^{\mathrm{e}}$-XIII ${ }^{\mathrm{e}}$ siècles), Positions des thèses soutenues par les élèves de la promotion de 1991 pour obtenir le diplôme d' archiviste-paléographe. Ecole Nationale des Chartres, s. 55-58.

27 Epistolae Ivonis, nr 64-65, s. 115 n. W sprawie datacji wciąż aktualne ustalenia A. F 1 i c h é, Le règne, s. 440-445; por. też R. S p r a n d e 1, Ivo von Chartres, s. 190. 
Morawy. Kronikarz odnotował także, co ma fundamentalne znaczenie, że wyprawa ta rozpoczęła się w oktawie Wielkiejnocy, a zatem albo pomiędzy 29 III a 5 IV 1103 r., albo między 17 IV a 24 IV 1104 r. ${ }^{28}$ Przyjazd legata byłby zaś w każdym z wypadków późniejszy o pewien bliżej nieokreślony czas. Gall nie poskąpił również czytelnikom wyjaśnienia, że książę uderzył na Morawy celem odwetu za niszczycielski najazd czeski, jaki spadł na Śląsk w trakcie uroczystości weselnych po zaślubinach Bolesława z księżniczką ruską Zbysławą. W roli zdrajcy występuje tam Zbigniew, który z zawiści wszedł w układy z Czechami ${ }^{29}$. Biorąc pod uwagę powszechnie znaną niechęć kronikarza do starszego brata Krzywoustego, można by posądzić go o stronniczość w przedstawianiu faktów, jednak ów najazd czeski na Śląsk z inspiracji Zbigniewa znany jest również Kosmasowi, który umieścił go pod 1103 r. ${ }^{30}$ Poprawność tej datacji wydatnie wzmacnia zapiska z Rocznika dawnego, w którym małżeństwo księcia Bolesława także widnieje pod 1103 r. ${ }^{31} \mathrm{~W}$ sprzeczności z danymi Kosmasa oraz rocznika nie stoi też informacja z Powieści minionych lat, gdzie pod 16 XI 1102 r. czytamy, że księżniczka Zbysława została wydana za mąż i wyruszyła do Polski ${ }^{32}$. Mając do wyboru 1103 oraz 1104 r. jako datę legacji Gwalona i chcąc opowiedzieć się za drugą możliwością, musielibyśmy założyć, że Zbysława ponad rok oczekiwała w Polsce na ślub z Bolesławem, co nie wydaje się prawdopodobne, nawet jeśli nupturienci potrzebowali dyspensy papieskiej ze względu na fakt zbyt bliskiego spokrewnienia. O tym zaś, że dyspensa ta była konieczna, dowiadujemy się znów z Galla, gdzie bezpośrednio przed opisem ślubu Bolesława i Zbysławy zapisał, iż: Sed pretermissis pluribus suo loco retractandis, de nupciis referamus eiusque [Bolesława] donis Bolezlaui magni regis muneribus comparandis.

${ }^{28}$ Gall, II 25, s. 92: Igitur beliger Bolezlauus iniurie Bohemorum vindicator tres acies militum in Moraviam transmissit, qui in ipsa ebdomada Dominice Resurrectionis euntes, et predam et incentia facientes dignam pene suis factis recompensationem invenerunt, quia tante solempnitatis reverentiam infregerunt.

29 Tamże, II 24, s. 91: Interea Zbigneus frater eius [Bolesława], qui vocatus ad nuptias fratris venire refutavit, cum Pomeranis et Bohemis amicitias federavit et dum nuptie fierent, ut ferunt, intrare Poloniam Bohemos animavit. Qui Bohemi per provinciam Wratislauiensem discurrentes et predas captivosque colligentes et incendia facientes, pluribus annis dampnum illi regioni (et) nocuum intulerunt.

${ }^{30}$ Cosmae Pragensis Chronica Boemorum, III 16, wyd. B. Bretholz, MGH Scriptores rerum Germanicarum, nova series, t. II, Berlin 1923, s. 179: Anno dominice incarnacionis MCIII. Izbigneu post obitum patris mox contra fratrum suum sumit arma et promittens pecuniam associat ducem Borivoy sibi in auxillium. Qui statim missit post Zuatopluk in Moraviam, et convenientes simul castra metati sunt iuxta oppidum Recen; thum. pol.: Kosmasa Kronika Czechów, opr. M. Wojciechowska, wyd. 3, Wodzisław Śląski 2012, s. 175.

${ }^{31}$ Rocznik dawny, wyd. Z. Kozłowska-Budkowa, MPH SN V, s. 12: Bolezlauus tercius duxit uxorem; zob. W. S e m k o w i c z, Rocznik tzw. świętokrzyski dawny, Rozprawy Polskiej Akademii Umiejętności, Wydział Historyczno-Filozoficzny 53, 1910, s. 272-274. W Roczniku kamienieckim małżeństwo przesunięto o rok do przodu (wyd. A. Bielowski, MPH II, s. 778: Bolezlaus tercius duxit uxorem Rutenam, de qua genuit Wlodzislaum).

32 Повесть временных леt, выд. Д. С. Лихачёв, t. I, Москва 1950, s. 183: „В тот же год повели дочь Святополка Сбыславу в Польшу за Болеслава, месяца ноября в 16-й день”; thum. pol.: Powieść minionych lat. Najstarsza kronika kijowska, opr. F. Sielicki, Wodzisław Śląski 2014, s. 192; por. O. B a 1 z e r, Genealogia Piastów, wyd. 2, Kraków 2005, s. 218-220; K. J a s iń s k i, Rodowód pierwszych Piastów, Warszawa [1992], s. 189 n. 
Quatenus autem hoc a Paschali papa secundo concessum fuerit, quod nuptias istas de consanguinitate licuerit, Balduinus Cracouiensis episcopus, ab eodem papa Rome consecratus, fidei ruditatem et patrie necessitatem intimavit, sicque Romane sedis auctoritas, ut fertur, hoc coniugium misericorditer, non canonice, nec usualiter, sed singulariter collaudavit ${ }^{33}$. Podróż Baldwina (biskupa krakowskiego od 1103 do $1109 \mathrm{r}^{34}$ ) do Rzymu, której przyświecały dwa zasadnicze cele, tj. uzyskanie dyspensy dla księcia oraz sakry biskupiej z rąk Paschalisa II, poświadcza również Rocznik kapituły krakowskiej. Koncentruje on wprawdzie uwagę tylko na konsekracji, ale jest całkowicie zgodny z narracją Galla, jeśli chodzi o sekwencję wypadków, tzn. najpierw Baldwin został wyświęcony w Rzymie, a dopiero potem przybył do Polski legat ${ }^{35}$. Innymi słowy, na gruncie zachowanych przekazów źródłowych widać bezsprzecznie, że o dyspensę postarano się przed zawarciem małżeństwa Krzywoustego ze Zbysławąa

Tym samym możemy ustalić właściwą chronologię wydarzeń. W listopadzie 1102 r. Zbysława wyruszyła na dwór Bolesława Krzywoustego, a wkrótce po jej przybyciu lub nawet z pewnym wyprzedzeniem wysłano Baldwina jako posła do Rzymu, aby uzyskał dla nowożeńców dyspensę, a dla siebie konsekrację na biskupa krakowskiego. Osiągnąwszy obydwa wyznaczone cele, powrócił do Polski, gdzie najpóźniej w marcu 1103 r. miały miejsce uroczystości weselne pary książęcej. Zanim się zakończyły, na Śląsk spadł najazd czeski, któremu Bolesław starał się przeciwstawić, wyprawiając się na Morawy w oktawie Wielkiejnocy. Po powrocie z ekspedycji gościł legata papieskiego, co miało miejsce zapewne w kwietniu-maju $1103 \mathrm{r}$.

Warto jeszcze postawić pytanie, w jakiej formie i kolejności mogły być umieszczone interesujące nas zapiski rocznikarskie o wydarzeniach z 1103 r. w tzw. Annales Regni Polonorum deperditi. W świetle dotychczasowych ustaleń historiografii nie ma bowiem wątpliwości, że wszystkie z przytoczonych roczników opierały się na

${ }^{33}$ Gall, II 23, s. 90; ostatnio na ten temat K. S k w i e r c z y ń s k i, Recepcja, s. 278-280; S. R o s i k, Bolesław Krzywousty, Wrocław 2013, s. 132-134.

${ }^{34}$ Szerzej o nim R. Gro d e c k i, Baldwin, w: Polski słownik biograficzny, t. I (1935), s. 231 n.; K. O ż ó g, Formacja intelektualna biskupów krakowskich w średniowieczu, w: Cracovia-Polonia-Europa. Studia z dziejów średniowiecza ofiarowane Jerzemu Wyrozumskiemu w sześćdziesiątą piątą rocznicę urodzin i czterdziestolecie pracy naukowej, Kraków 1995, s. $161 \mathrm{n}$.

${ }^{35}$ Rocznik kapituły krakowskiej, MPH SN V, s. 54 (pod 1103: Balduinus Rome consecratus est in episcopum Cracouiensem); bezpośrednio potem zapiska o legacji (zob. przyp. 6); zob. też Rocznik świętokrzyski, wyd. A. Rutkowska-Płachcińska, MPH SN XII, Kraków 1996, s. 21 (pod 1101: Lambertus episcopus obiit. Cui succedit Balduinus, qui in episcopatum Rome consecratur). Przez pośrednictwo roczników wywodzących się z Annales Regni Polonorum deperditi fakt ten dotarł też do katalogów biskupów krakowskich (począwszy od redakcji II): Katalogi biskupów krakowskich, wyd. J. Szymański, MPH SN X/2, Warszawa 1974, s. 28, 46, 55 n., 86, 110.

36 Odwrotną kolejność, tzn. najpierw legacja, a potem podróż Baldwina i małżeństwo księcia, sugerowali np. P. D a vi d, Un disciple, s. 109-113, oraz Z. K o złow s k a - B u d k ow a, Repertorium polskich dokumentów doby piastowskiej, wyd. 2, Kraków 2006, nr 17, s. 74 n.; t a ż, Wstęp, w: MPH SN V, s. XXXVIII. Najpierw trzeba byłoby jednak wykazać, że zarówno Gall, jak i Annales Regni Polonorum deperditi, z których wywodzą się zachowane roczniki, przekazały błędną chronologię wydarzeń. 
zaginionym oryginale ${ }^{37}$. Wydaje się, że pierwotnie była to jedna rozbudowana zapiska, która z biegiem lat uległa rozszczepieniu na kilka mniejszych, czemu mogło towarzyszyć przesunięcie danego faktu np. o rok. Dokładnego jej brzmienia oczywiście nie odtworzymy, ale wyglądać mogła zapewne tak: Balduinus Rome consecratus in episcopum Cracouiensem. Bolezlauus tercius duxit uxorem. Gualo episcopus Beluacensis sedis apostolice legatus intrat Poloniam et duos episcopos deponit/deposuit, lub podobnie.

\section{KTÓRZY BISKUPI ZOSTALI USUNIĘCI Z GODNOŚCI PRZEZ LEGATA?}

Jak powszechnie wiadomo, polska prowincja kościelna składała się na początku XII w. z arcybiskupstwa gnieźnieńskiego oraz czterech podległych metropolicie biskupstw: krakowskiego, wrocławskiego, poznańskiego i płockiego. Zarówno Kronika Galla, jak i zapiski rocznikarskie nic nie wiedzą o depozycji arcybiskupa, toteż krąg naszych poszukiwań ogranicza się de facto do czterech ordynariuszy diecezji. Z grona potencjalnych oskarżonych możemy jednak wyłączyć biskupa wrocławskiego. Upoważniają do tego zapisy katalogów biskupów tej diecezji, które, choć zachowane w późnośredniowiecznych redakcjach, wywodzą się jednak z zaginionego, pierwotnego katalogu, prowadzonego na bieżąco, począwszy od XI w.; jego istnienie poświadczone jest źródłowo od pierwszej połowy XIII w. ${ }^{38}$ Pod koniec pierwszej połowy XII w. imiona wcześniejszych hierarchów wraz z datami ich ordynacji i śmierci, dzięki pośrednictwu biskupa Roberta, który piastując pierwotnie biskupstwo wrocławskie (1126-1140), został przeniesiony na krakowskie, dostały się również do Annales Regni Polonorum deperditi ${ }^{39}$. Nas zainteresuje biskup Piotr I, sprawujący

${ }^{37}$ W. K o r t a, Średniowieczna annalistyka śląska, Wrocław 1966, s. 31-94, zwł. s. 72 n.; G. L a b u d a, Roczniki polskie, w: Słownik starożytności słowiańskich, t. IV, Wrocław 1970, s. 510-512; Z. K o zło w s k a - B u d k ow a, Wstęp, w: MPH SN V, s. XXX-XLII; W. D r e 1 i c h a r z, Annalistyka małopolska XIII-XV wieku. Główne kierunki rozwoju wielkich roczników kompilowanych, Kraków 2003, s. 374-449; t e n że, Idea zjednoczenia królestwa w średniowiecznym dziejopisarstwie polskim, Kraków 2012, s. 22-47.

${ }^{38}$ Katalogi biskupów wrocławskich, wyd. W. Kętrzyński, MPH VI, Lwów 1893, s. 534-585 (wstęp, s. 534-557); zob. też F. S c h u l t e, Zu den Breslauer Bischofskatalogen, Zeitschrift für Geschichte Schlesiens 44, 1910, s. 207 n.; O. S c h m i d t, Untersuchungen zu den Breslauer Bischofskatalogen, Breslau 1917, zwł. s. 12 n., 17 n., 54 n., 88 n., 130; A. B ir k e n maj e r, Nowy katalog biskupów wrocławskich, w: Studia historyczne ku czci Stanisława Kutrzeby, t. II, Kraków 1938, s. 29-40; T. S i 1 n i c k i, Dzieje i ustrój Kościoła katolickiego na Śląsku do końca w. XIV, Warszawa 1953, zwł. s. 9, 32-35, J. S z y m a ń s k i, W sprawie genezy rocznikarstwa śląskiego, Studia Źródłoznawcze (dalej cyt.: SŹ) 22, 1977, s. 77 n.; E. P o t k o w s k i, Fiktive Biographien in den Katalogen polnischer Bischöfe des Jan Długosz, w: Fälschungen im Mittelalter, t. I, Hannover 1988, s. 395-416, zwł. s. 404 n., 415; T. J u r e k, Ryczyn biskupi. Studium z dziejów Kościoła polskiego w XI w., Roczniki Historyczne 60, 1994, zwł. s. 22 n., 26, 47 n., 56.

39 J. S z y m án s ki, Krakowski epizod biskupa Roberta, w: Cultus et cognitio. Studia z dziejów średniowiecznej kultury, Warszawa 1976, s. 573-577; Z. K o zło w s k a - B u dk ow a, w: MPH SN V, s. 56 (przyp. 170), 58 (przyp. 80-81); K. O żó g, Robert, w: Polski słownik biograficzny, t. XXXI (1988), s. 327 n.; T. J u r e k, Zagadka biskupa wrocławskiego Roberta, Śląski Kwartalnik Historyczny Sobótka 45, 1990, s. 1-11, zwł. s. 8 n. 
rządy nieprzerwanie od 1074 do 1111 r. Jego postać nieobca jest również niektórym rocznikom, które odnotowały datę zarówno jego ordynacji, jak i śmierci ${ }^{40}$. Opierając się na tych przekazach, możemy stwierdzić z pewnością, że zachował on swój urząd po legacji Gwalona.

W kręgu poszukiwań pozostają zatem biskupi krakowski, poznański i płocki. W literaturze nie było jak dotąd zgody, o których z nich chodziło Gallowi. Uwagę historyków przykuwa zatem od dawna ogłoszony przez Augusta Bielowskiego najstarszy znany spis inwentarza skarbca i biblioteki kapituły krakowskiej, sporządzony na samym początku XII w. Czytamy w nim: Anno D(omi)nice incarnationis MCI indictione VIII defuncto reuerentissime presule ac bonę memorię Lamberto, datus est episcopatus uenerabili viro Cazlao ab inuictissimo duce Polonorum Wladizlao, quibus complacuit, ut ornamenta ęcclesię inscripta haberentur, idcirco ne quis clericorum vel

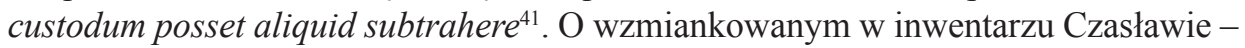
nominacie księcia Władysława Hermana na biskupstwo krakowskie i bezpośrednim poprzedniku Baldwina - nic nie wiemy z innych źródeł, jednak musiał on otrzymać nominację w listopadzie-grudniu 1101 r., gdyż Rocznik dawny i Kalendarz katedry krakowskiej pozwalają datować śmierć jego poprzednika Lamberta na 25 XI $1101 \mathrm{r}^{42}$ Czesława nie wymieniają inne źródła, nie wspominają o nim roczniki, zapisy kommemoratywne ani żadne przeddługoszowe katalogi biskupów krakowskich. Dało to asumpt do hipotezy, że o hierarsze tym celowo zdecydowano się z jakiegoś powodu zapomnieć43 ${ }^{43}$ Uwzględniając zaś bliskość chronologiczną jego nominacji i wzmianki

${ }^{40}$ Katalogi biskupów wrocławskich, MPH VI, s. 558 (katalog henrykowski: Tertius episcopus Petrus ordinatus est anno Domini MLXXIIII. Obiit anno Domini MCXI [w rękopisie: $M C X I I]$ ), podobnie s. 560 (katalogi lubiąski i głogowski), 566, 576 (niemalże identyczne zapisy w Series episcoporum Wratislaviensium, katalogu krzeszowskim i tzw. Stenzlowskim oraz w Cronica et numerus episcoporum Wratislaviensium). Zob. Rocznik kapituły krakowskiej, MPH SN V, s. 50 (1074: ordinacio Petri episcopi Wratizlauiensis), 55 (1110: Petrus episcopus Wratizauiensis obiit); identyczne wzmianki o ordynacji zawierają też Rocznik kamieniecki, MPH II, s. 778 oraz Rocznik Sędziwoja, MPH II, s. 874. Por. też Z. L e c, Wiadomości o pierwszych biskupach śląskich w świetle kroniki Thietmara i niektórych wrocławskich katalogów biskupich, Śląski Kwartalnik Historyczny Sobótka 53, 1998, s. 484-486; J. D o b o s z, Monarcha i możni, s. 234-236.

${ }^{41}$ MPH I, Lwów 1864, s. 376. Na temat tego inwentarza oraz kolejnego (sporządzonego w 1110 r.) zob. A. Vet u l a n i, Krakowska biblioteka katedralna w świetle swego inwentarza z roku 1110, Slavia Antiqua 4, 1953, s. 163-191; L. K a l i n o w s k i, Najstarsze inwentarze skarbca katedry krakowskiej jako źródło do dziejów sztuki w Polsce, w: Cultus et cognitio (jak w przyp. 39), s. 217-231; M. P 1 e z i a, Księgozbiór katedry krakowskiej wedle inwentarza z r. 1110, w: Silva rerum. Series nova, wychodzi jak jest gotowa..., Kraków 1981, s. 16-28.

${ }^{42}$ Zob. Rocznik dawny, MPH SN V, s. 12; Kalendarz katedry krakowskiej, wyd. Z. Kozłowska-Budkowa, tamże, s. 188; zob. R. G r o d e c k i, Czasław, w: Polski słownik biograficzny, t. IV (1938), s. 304; A. Wędzki, Czasław, w: Słownik starożytności słowiańskich, t. I (1961), s. 284; M. K o s o n ow s ki, Postać i panowanie, s. 253-255.

${ }^{43}$ A. Ve tu l a n i, Krakowska biblioteka, s. 169; Z. K o zło w s k a - B u d k o w a, w: MPH SN V, s. 53 n. (przyp. 49); J. S z y m a ń s k i, Wstęp, w: MPH SN X/2, s. 10; G. L a b u d a, Katalogi biskupów krakowskich przed Długoszem, SŹ 27, 1983, s. 84; P. W i s z e w s ki, Domus Bolezlai. W poszukiwaniu tradycji dynastycznej Piastów (do około 1138 roku), Wrocław 2008, s. 114, 126; A. K r a w i e c, Król bez korony. Władysław I Herman, książę polski, Warszawa 2014, s. 79, 161, 265-267; P. N ow a k, Legacja Galona, s. 429. 
o Gwalonowych depozycjach, uznano, że najpewniej to on właśnie został złożony wtedy z godności. Za ojca tak sformułowanej hipotezy należy uznać Jana Długosza, który jako pierwszy wykorzystał wspomniany inwentarz katedralny i ustosunkował się do sprawy Czasława dwukrotnie - w swym Katalogu biskupów krakowskich oraz w IV księdze Roczników. W tym drugim dziele pisze: Summi pontificis Paschalis secundi nuncius cum potestate legati de latere Gwaldo episcopus Belwaczensis in Poloniam Boleslao de Moravica expeditione redeunti venit. Qui a Boleslao comiter exceptus, Polonica visitata, prout a summo pontifice iussus erat, Ecclesia et rigorem iusticie inscelatores, ducis Boleslai illum animante acuenteque assistencia, duos provinicie Gneznensis episcopos culpa exigente dampnavit et suis per sentenciam deposicionis privavit sedibus. Qui tamen hii fuerint et quarum ecclesiarum episcopi, vario et dilligenti in quibuslibet annalibus scrutinio facto legisse me non meminerim. Reor tamen ex coniectura evidenti, quod unus episcoporum depositorum fuit Czyslawus, qui Cracoviensem episcopatum nulla summi pontificis auctoritate, sed sola ducis Polonie Wladislai donatione detinebat ${ }^{44}$. Śladem wytyczonym przez rozumowanie Długosza poszedł następnie Adam Naruszewicz ${ }^{45}$, za pośrednictwem którego pogląd ten dostał się do późniejszej historiografii i zachował w niej żywotność aż do czasów współczesnych. Zaszła jednak zasadnicza zmiana w odniesieniu do przyczyny domniemanej depozycji Czasława. O ile bowiem w ujęciach Długosza i Naruszewicza powodem jego złożenia z godności był fakt, że otrzymał godność bez wiedzy papieskiej, o tyle ich następcom bardziej prawdopodobne wydawało się niezachowanie przez hierarchę celibatu. Dodatkowym argumentem na rzecz takiej rekonstrukcji wydarzeń miałaby być lista świadków w tzw. dokumencie radziejowskim księżnej Salomei z przełomu lat trzydziestych i czterdziestych XII w., gdzie widnieje m.in. Andreas filius episcopi Cechawy (co interpretowano jako ,syn biskupa Czasława"46). Wprawdzie we wszystkich edycjach krytycznych słowa episcopi i Cechawy zostały oddzielone przecinkiem, ale nie stanowiło to dla późniejszych badaczy przeszkody do przyjęcia, że te stojące obok siebie wyrazy tworzą logiczną

${ }^{44}$ Ioannis Dlugossii Annales seu cronicae incliti Regni Poloniae, lib. III-IV, Varsaviae 1970, s. 217 (pod 1104); tłum. pol.: Jana Długosza Roczniki, czyli kroniki sławnego Królestwa Polskiego, ks. III-IV, thum. J. Mrukówna, Warszawa 1969, s. 263 n.; zob. też Katalogi biskupów krakowskich, MPH SN X/2, s. $150 \mathrm{n}$.

${ }^{45}$ A. N a r u s z e w i c z, Historia narodu polskiego od początku chrześcijaństwa, t. III, Warszawa 1781, s. 105-107 (tu zestawienie najważniejszych głosów doby staropolskiej).

${ }^{46}$ A. B i e low s ki, w: MPH I, s. XXVI-XXIX; Kodeks dyplomatyczny Wielkopolski, t. I, [wyd. I. Zakrzewski], Poznań 1877, nr 9, 33; Zbiór dokumentów średniowiecznych do objaśniania prawa polskiego ziemskiego służących, wyd. F. Piekosiński, Kraków 1897, nr 7. O dokumencie tym, znanym jedynie w formie transumptu Mieszka Starego, zachowanego w dwóch siedemnastowiecznych kopiach, piszę w innym miejscu: M. K o s o n o w s ki, Dokumenty księżnej Salomei i księcia Mieszka Starego dla klasztoru Benedyktynów w Mogilnie z XVII-wiecznego kopiariusza Archiwum Krakowskiej Kapituły Katedralnej. Studium krytyczne i edycja tekstu, w: Signa. Studia i szkice z nauk pomocniczych historii. Prace dedykowane Profesorowi Zenonowi Piechowi w sześćdziesiątą rocznicę urodzin, Kraków 2014, s. 29-58 (na s. 48-58 nowa edycja, na podstawie której cytuję dalej ten tekst). Zauważyć trzeba, że obie kopie zostały wciągnięte do klasztornego kopiariusza tą samą ręką, a tylko w jednej $\mathrm{z}$ nich występuje interesujący nas świadek; w drugiej odpowiedni passus brzmi: Radzislaw filius Cechowy, Zyzema comes (tamże, s. 50). 
całość, a więc biskup rzeczywiście miał syna ${ }^{47}$. Nie zabrakło też głosów, które nie negując depozycji Czasława przez legata, kwestionowały jednak przedstawione uzasadnienie i stwierdzały przeważnie, że powodem całego zajścia był konflikt personalny między księciem a biskupem albo też pozostawanie Czasława w obediencji ówczesnego antypapieża ${ }^{48}$.

Warto wszakże podkreślić, że pogląd o usunięciu Czasława przez Gwalona nie jest oparty na żadnym zapisie źródłowym, z czego zdawał sobie sprawę już Jan Długosz. Nie ma zatem powodu, aby kurczowo trzymać się wyrażonego przezeń domysłu, zwłaszcza że kilka przesłanek nie świadczy na jego korzyść. Pierwsza z nich wynika z chronologii wypadków. Skoro, jak ustaliśmy, podróż Baldwina do Rzymu poprzedziła wizytę legata w Polsce, to nie wydaje się, aby rozpatrywał on na miejscu ponownie sprawę obsady biskupstwa krakowskiego, uregulowaną już przecież bezpośrednio przez papieża. Po drugie zaś w dotychczasowej debacie zbyt mało, naszym zdaniem, eksponowano inne możliwości wyjaśnienia enigmatycznych losów Czasława. Równie prawdopodobna jest bowiem hipoteza, że umarł on jeszcze przed konsekracją albo wkrótce po niej, co spowodowało, że pamięć o nim mogła nie zaznaczyć się w źródłach ${ }^{49}$. Pogląd o usunięciu biskupa przez Gwalona (lub wcześniej przez synod krajowy czy osobiście przez Bolesława Krzywoustego) nosi też wszelkie znamiona błędnego koła argumentacyjnego; dowodem na depozycję biskupa ma być źródłowa damnatio memoriae, którą zakłada się na tej podstawie, że został złożony z godności... Nie można zatem zgodzić się z taką rekonstrukcją wydarzeń.

${ }^{47}$ Np. W. A b r a ha m, Organizacja Kościoła w Polsce do połowy wieku XII, wyd. 4, Wodzisław Śląski 2009, s. 204-210, zwł. s. 209 n.; t e n ż e, Początek biskupstwa i kapituły katedralnej w Krakowie, Rocznik Krakowski 4, 1900, s. 194-196 (przedruk w: tegoż, Organizacja Kościoła, s. 304-306); T. W o j c i e c h o w s k i, Szkice historyczne XI wieku, wyd. 4, Warszawa 1970, s. 269 n.; A. M a ł e c k i, W kwestii fałszerstwa dokumentów, Kwartalnik Historyczny (dalej cyt.: KH) 18, 1904, s. 449-458, zwł. s. 450; ks. W. W ó j c i k, Prawo celibatu w Polsce średniowiecznej, Roczniki Teologiczno-Kanoniczne 5, 1958, s. 59 n.; A. G i e y s zt or, Przemiany ideologiczne w państwie pierwszych Piastów a wprowadzenie chrześcijaństwa, w: Początki państwa polskiego. Księga Tysiąclecia, t. II, Poznań 1962, s. 161; S. S z c zur, Kościół krakowski a Stolica Apostolska we wczesnym średniowieczu, Analecta Cracoviensia 32, 2000, s. XLVI-XLIX; K. S kwierc zyń s ki, Recepcja, s. $278-285,306-308$.

${ }^{48}$ Np. Z. S u ło w s k i, Początki Kościoła polskiego, w: Kościół w Polsce, Kraków 1966, s. 100, 113; U. B o rk ow s k a OSU, Odbudowa i rozwój (2. poł. XI i XII w.), w: Chrześcijaństwo w Polsce. Zarys przemian 966-1979, Lublin 1992, s. 66; J. D o b o s z, Monarcha i możni, s. 171-175; T. N o w a k o w s k i, Źródła Jana Długosza do dziejów Mazowsza w XIXIV wieku. W poszukiwaniu rocznika płockiego, Bydgoszcz 2012, s. 234-236. Wyraźnego stanowiska nie zajęli D. von Güttner-Sporzyński, Poland and the papacy before the Second Crusade, w: La papauté et les crosaides, Farnheim 2011, s. 257-260; S. R o s i k, Bolesław, s. 130-136.

49 Pamięć o biskupie powinna być jeszcze żywa, gdy ok. 1120 r. powstawał Rocznik dawny, który jednak tylko wyjątkowo uwzględnia wiadomości o biskupach, a z krakowskich wspomina tylko Lamberta (zm. 1101) - zob. K. J a s i ń s k i, Najstarsze roczniki krakowskie, KH 88, 1981, s. 468 n.; J. B i e n i a k, Autor Rocznika dawnego, w: Kultura średniowieczna i staropolska. Studia ofiarowane Aleksandrowi Gieysztorowi w pięćdziesięciolecie pracy naukowej, Warszawa 1991, s. 429-432. 
Po wykluczeniu biskupów wrocławskiego i krakowskiego jako kandydaci do depozycji pozostają zatem tylko ordynariusze z Poznania i Płocka ${ }^{50}$. Niestety nie możemy wskazać ich imion, pochodzenia ani daty i okoliczności objęcia rządów. Wprawdzie w historiografii podejmowano liczne próby związania z Kościołem polskim przełomu XI i XII w. takich biskupów, jak Ederam (w Poznaniu), Eberhard (w Kruszwicy), Eckhard (?) oraz Henryk (w Płocku) ${ }^{51}$, jednak w znacznej mierze kończyły się one fiaskiem. O Ederamie wiemy, dzięki badaniom Zofii Kozłowskiej-Budkowej, że umarł przed 1049 r., kiedy to spisana została warstwa nekrologu klasztoru św. Emmerama w Ratyzbonie, w której figuruje to imię ${ }^{52}$. Aleksander Gieysztor z kolei wykazał, że biskupa polskiego Eckharda w ogóle nie umiemy precyzyjnie umiejscowić w czasie, gdyż jego imię widnieje na liście kanoników wspólnoty św. Szymona i Judy Tadeusza w Goslarze, powołanych na biskupstwa pomiędzy Herbertem z Leodium a Godfrydem z Ratyzbony, o których nie wiemy z pewnością, kiedy sprawowali rządy ${ }^{53}$. Domysł o rezydowaniu Eberharda w Kruszwicy obalił Gerard Labuda, wykazując, że przed legacją Idziego z Tusculum w 1123/1124 r. biskupstwo kruszwickie w ogóle nie istniało $^{54}$. Wreszcie sam pomysł włączenia do episkopatu polskiego biskupów Henryka i Eberharda ze znanego dokumentu Władysława Hermana dla katedry w Bambergu stanął pod poważnym znakiem zapytania, zgodnie bowiem z najnowszymi badaniami nie byli to biskupi, lecz wysocy dostojnicy kapituły bamberskiej, dysponujący prawem do używania pontyfikaliów, dlatego łatwo było ich pomylić ${ }^{55}$. Jedynie dwaj

${ }^{50}$ Do takiego wniosku skłaniali się już wcześniej M. G ę b a ro w i c z, Walo, biskup Beauvais i Paryża i jego legacyja w Polsce, Sprawozdania Towarzystwa Naukowego we Lwowie 3, 1923, s. 68-71; K. M a l e c z y ń s k i, rec. z: Z. Kozłowska-Budkowa, Repertorium, KH 51, 1937, s. 577 n.; t e n ż e, Bolesław III Krzywousty, wyd. 2, Kraków 2010, s. 62, 291 n., 297-304 (w pierwszej wersji tej biografii, jeszcze bez aparatu krytycznego, pt. Bolesław Krzywousty. Zarys panowania, Kraków [1946], s. 184, 188-191); J. Ta z b i r o w a, Początki biskupstwa na Kujawach, Przegląd Historyczny 53, 1962, zwł. s. 236-244. W studiach tych udowodniono wprawdzie, że Gall Anonim i rocznikarze przekazali identyczną chronologię wypadków, ale zbyt słabo, naszym zdaniem, akcentowano, że tę chronologię da się uzgodnić ze świadectwem źródeł obcych, co ma kluczowe znaczenie dla całej sprawy.

${ }^{51} \mathrm{~K}$. M a l e c z y ń s ki, W sprawie nieznanego biskupa polskiego Henryka z XI wieku, Sprawozdania Towarzystwa Naukowego we Lwowie 17, 1937, s. 222-226; t e n ż e, Bolesław III, s. 62, 291 n., 297-304.

${ }_{52}$ Z. K o złow sk a - B u d k ow a, Który Bolesław?, w: Prace z dziejów Polski feudalnej ofiarowane Romanowi Grodeckiemu w 70. rocznicę urodzin, Warszawa 1960, s. 86; zob. Necrologium Weltenburgense, wyd. F. L. Baumann, MGH Necrologia, t. III, Berolini 1905, s. 382 (III. Kal. Decembrii Ederammus eps. de Polania); Necrologium monasterii S. Emmeramii Ratisbonensis, wyd. F. L. Baumann, tamże, s. 331 (III Kal. Decembrii Ederammus eps.) oraz s. 301 (gdzie o rękach pisarskich).

${ }^{53}$ A. G i e y s z t o r, O kilku biskupach polskich XI wieku, w: Europa - Słowiańszczyzna - Polska. Studia ku uczczeniu profesora Kazimierza Tymienieckiego, Poznań 1970, s. 321-326.

${ }^{54}$ G. L a b u d a, Początki diecezjalnej organizacji kościelnej na Pomorzu i na Kujawach w XI i XII wieku, Zapiski Historyczne 33, 1968, s. 19-60, zwł. s. 44 n. Dalszą dyskusję referują H. Ło w m i á s k i, Początki Polski, t. VI, cz. 1, Warszawa 1985, s. 370-375; M. M i c h a ls k i, Ustanowienie i wczesne dzieje biskupstwa kujawskiego, w: Scripta minora, t. I, Poznań 1996, s. 83-108.

${ }_{55}$ Die Regesten der Bischöfe und des Domkapitels von Bamberg, opr. E. von Guttenberg, Würzburg 1963 (Veröffentlichungen für fränkische Geschichte, VI. Reihe), s. 250 n.; 
Henrykowie, wymieniony w Żywocie św. Ottona z Bambergu pióra mnicha Ebona ${ }^{56}$ oraz figurujący w odpisie Libri fraternitatis klasztoru św. Michała w Siegburgu, sporządzonym dla kapituły w Canterbury przed 1125 r. ${ }^{57}$, mogli wchodzić w skład polskiego episkopatu na przełomie XI i XII w. ${ }^{58}$

Równie trudne jest poszukiwanie potencjalnych następców zdeponowanych hierarchów. Wprawdzie Gall, piszący ok. 1115 r., wymienia w liście dedykacyjnym do księgi I biskupa Pawła (zapewne poznańskiego ${ }^{59}$ ), jednak nie znamy daty jego ordynacji. Identycznie wygląda sytuacja ze wspominanym dwukrotnie przez Jana Długosza Filipem, który miałby po legacji Gwalona rządzić w Płocku, a w 1107 r. jego miejsce zająłby Szymon znany z kroniki Galla ${ }^{60}$. Jak słusznie zauważył bowiem ostatnio Tomasz Nowakowski, biskupa Filipa nie zna żadne z wcześniejszych źródeł, stąd trudno orzec, czy w ogóle istniał, zwłaszcza że w Długoszowych katalogach fakty często mieszają się z fantazją ${ }^{61}$.

W konkluzji zatem stwierdzamy, że dwaj biskupi zdeponowani przez Gwalona w 1103 r. nie zasiadali na stolicach we Wrocławiu i Krakowie, co automatycznie oznacza, że musieli to być biskupi poznański i płocki. Nic pewnego o nich jednak nie wiemy.

\section{PRZYCZYNY AKCJI DEPOZYCYJNEJ GWALONA}

W dotychczasowej dyskusji starano się wytłumaczyć decyzję legata o usunięciu dwóch polskich biskupów czterema zasadniczymi przyczynami: a) współdziałaniem Gwalona z Bolesławem Krzywoustym, który zabiegał o depozycję stronników Zbigniewa ${ }^{62}$,

w literaturze polskiej: A. G i e y s zt o r, Bamberg i Polska w XI i XII wieku, SŹ 15, 1971, s. 74; J. S tr z e l c z y k, Bamberg a Polska w średniowieczu, Roczniki Historyczne 62, 1996, s. 77 n.; P. W i s z e w s k i, Domus Bolezlai, s. 95; A. K r a w i e c, Król bez korony, s. 148 n.

${ }_{56}$ Ebonis Vita s. Ottonis, I 3, wyd. J. Wikarjak, K. Liman, MPH SN VII, cz. 2, Warszawa 1969, s. 12 n.

57 The Monuments of the Dean and Chapter of Canterbury, w: Historical Manuscript Commission. Report of Manuscript in Various Collections, wyd. R. S. Poole, London 1901, s. 217 (VIII. Id. Iulii obiit Heinricus, sacerdos et monachus eiusdem loci [klasztoru św. Michała] et episcopus Polonensis).

${ }_{58}$ Za przynależnością pierwszego z nich do polskiego episkopatu oświadczył się ostatnio G. L a bu d a, Arcybiskup Henryk - arcybiskup Bogumił - arcybiskup Bogumił-Piotr, w: tegoż, Szkice historyczne X-XI wieku. Z dziejów organizacji Kościoła w Polsce we wczesnym średniowieczu, Poznań 2004, s. 381-385, zastrzegając jednak, że był to biskup, a nie arcybiskup (jak przyjmowali T. W o j c i e c h o w s k i, Szkice, s. 199-225, oraz ks. J. N o w a ck i, Dzieje archidiecezji poznańskiej, t. I, Poznań 1958, s. 32).

${ }^{59}$ Dane źródłowe na jego temat zebrał A. G ą s i o r o w s k i, Paweł, w: Słownik starożytności słowiańskich, t. IV (1970), s. 49.

${ }^{60}$ Ioannis Dlugossii Annales, lib. III-IV, s. 227; Ioannis Dlugossii Vitae episcoporum Plocensium abbreviatae cum continuatione Laurentii de Wszerecz, wyd. W. Kętrzyński, MPH VI, Kraków 1893, s. 601.

${ }^{61}$ T. N o w a k o w s k i, Źródła Jana Długosza, s. 232-235 (tu przegląd dawniejszej literatury). Mimo podniesionych zastrzeżeń ordynację Filipa na synodzie zwołanym przez Gwalona uznaje ks. T. Ż e b r o w s k i, Kościół X-XIII wiek, w: Dzieje Mazowsza do 1526, Warszawa 1994, s. 138.

${ }^{62}$ Tak przede wszystkim J. Ta z b i r o w a, Początki biskupstwa, s. 236-244; J. D o b o s z, Monarcha i możni, s. 171-175; tenże, E. Skibiński, The Church in the Gallus 
b) chęcią walki legata z praktykami nikolaickimi wśród kleru ${ }^{63}$, c) faktem pozostawania obydwu hierarchów w obediencji antypapieża ${ }^{64}$ oraz d) racjami wynikającymi z przepisów prawa kanonicznego, zgodnie z którymi metropolita nieposiadający paliusza nie może wyświęcać nowych biskupów (dwaj usunięci mieli w tym ujęciu nieważną sakrę ${ }^{65}$ ). Pierwsza próba wyjaśnienia nie budzi na ogół wątpliwości. Legat, przybywszy do kraju zupełnie sobie nieznanego, musiał szukać sojusznika w osobie panującego księcia, dzięki któremu udało mu się zwołać synod. Czy Gwalo stał się jednak tylko narzędziem Bolesława w jego staraniach o neutralizację szkodliwych dla siebie wpływów w polskim episkopacie? Wydaje się to dość wątpliwe, zwłaszcza że legat był, jak wiemy, człowiekiem wysoce wykształconym, biegłym w prawie, umiarkowanym zwolennikiem reformy gregoriańskiej, wobec czego można oczekiwać, że przybywał nad Wisłę z jakimś własnym programem reformatorskim. Czy obejmował on jednak walkę z nieprzestrzeganiem celibatu wśród duchowieństwa? Wydaje się to wątpliwe.

Aby zilustrować nasze wątpliwości, odwołamy się do niewykorzystanych dotąd w dyskusji nad wizytą Gwalona w Polsce dokumentów wystawionych przez legatów Stolicy Apostolskiej w różnych krajach chrześcijańskich oraz do innych przekazów mówiących o ich działalności za pontyfikatu Paschalisa II ${ }^{66}$. Najpełniejsze (choć wciąż niewyczerpujące) zestawienie tego materiału, przygotowane przez Stefana Weißa ${ }^{67}$, zwraca uwagę na zastanawiającą prawidłowość. Otóż na blisko 90 uwzględnionych tam przekazów (głównie dokumentów) znacząca większość dotyczy rozwiązywania spraw administracyjnych, a żaden nie dotyka problemu walki z nikolaityzmem. Fakt ten można uznać za znaczący. Nie tu miejsce na szczegółową analizę tych dyplomów, można jednak dokonać wstępnej typologii tego materiału, dzieląc go na dokumenty dotyczące: a) rozstrzygania sporów o prawo własności (kościoła, kaplicy, hospicjum),

Anonymous' chronicle - Gallus within the Church, w: Gallus Anonymous and His Chronicle in the Context of Twelfth-Century Historiography from the Perspective of the Latest Research, Kraków 2010, s. 80; A. K r a w i e c, Król bez korony, s. 265-267.

${ }^{63}$ Zob. literaturę z przyp. 47 (z wyłączeniem T. Wojciechowskiego); por. też Historia Kościoła w Polsce, t. I, cz.1, Poznań 1974, s. 61, 72.

${ }^{64}$ Zob. np. T. Wo j c i e c how s ki, Szkice, s. 269 n.; M. G ę b a row i c z, Walo, s. 70; T. N ow a k ow s k i, Źródła Jana Długosza, s. 232-234. Wyraźnego stanowiska nie zajmuje K. M a le c z y ń s k i, Bolesław III, s. 62, 297-299, choć jego poglądy raczej sytuują go w tej grupie badaczy.

65 J. K a r w a s i ń s k a, Archiepiscopus Polonie - archiepiscopus Gneznensis. O adresacie bulli Paschalisa II, SŹ 27, 1983, s. 48-50. Zapowiedź tego poglądu odnajdujemy u S. S m o 1 k i, Mieszko Stary i jego wiek [1881], wyd. 3, Kraków 2009, s. 181 n., 499, zdaniem którego legację Gwalona należy wiązać z zabiegami arcybiskupa Marcina o paliusz.

${ }_{66}$ Pontyfikat ten był bardzo bogaty w misje legatów. Pogląd ogólny na tę kwestię dał P. B l e t, Histoire de la répresentation diplomatique du Saint Siège des origines à l'aube du $\mathrm{XIX}^{\mathrm{e}}$ siècle, Città del Vaticano 1982, s. 111-117. Z ujęć analitycznych zob. O. S c h u m a n n, Die päpstlichen Legaten in Deutschland zur Zeit Heinrichs IV. und Heinrichs V. (1056-1125), Marburg 1912, s. 79-106; H. Ti 11 m a n n, Die päpstlichen Legaten in England bis zur Beendung der Legation Gualas (1218), Bonn 1926, s. 22-27; T. S c h i effer, Die päpstlichen Legaten, s. 163-214; C. S e r v a t i u s, Paschalis II. (1099-1118), Stuttgart 1979 (Päpste und Papsttum 14), s. 18-32, 42-58, 93-95, 146-150.

${ }^{67}$ S. W e i $ß$, Die Urkunden, s. 38-78 (tam też szczegółowa dokumentacja). 
dziesięciny i należne opłaty na rzecz podmiotów świeckich bądź duchownych; b) poświęcenia przez legata kościoła (kaplicy, cmentarza itp.); c) wzywania hierarchów Kościoła do udziału w synodach lub innych zgromadzeniach kanonicznych, klasztorów do przyjęcia nowych przełożonych, a duchowieństwa świeckiego do przyjęcia odpowiednich kandydatów na beneficja (w tym na biskupstwa); d) informowania o ekskomunikowaniu (lub polecenia ekskomunikowania) danej osoby (także całych klasztorów) bądź o nałożeniu innej kary kościelnej za samowolne złamanie posłuszeństwa wobec bezpośrednich przełożonych; e) przywilejów dla osób świeckich bądź duchownych. Wydaje się zatem, że wysłannicy papiescy za czasów Paschalisa II służyli przede wszystkim stopniowemu i konsekwentnemu budowaniu w Kościołach partykularnych zasady prymatu papieskiego, zgodnie z którą Stolica Apostolska zaczynała być postrzegana (co wcześniej bynajmniej nie było oczywistością) jako jedna z najważniejszych, jeśli nie najważniejsza, instancja odwoławcza w rozwiązywaniu wielu spraw lokalnych, jako nie tylko duchowe, ale również administracyjne centrum chrześcijaństwa, przez co tworzono warunki do stopniowej infiltracji idei i postulatów reformy gregoriańskiej w poszczególnych krajach ${ }^{68}$. Troska o zaprowadzenie dyscypliny moralnej wśród duchowieństwa świeckiego musiała także odgrywać ważną rolę, ale z powyższego zestawienia widać, że nawet w państwach o wielowiekowych tradycjach chrześcijańskich reforma gregoriańska postępowała stopniowo i nie miała na początku XII w. takiego impetu, jak za czasów Grzegorza VII. Zbytni pośpiech w jej wprowadzaniu mógłby zrodzić dodatkowe animozje, a temu Stolica Apostolska starała się zapobiegać, zwłaszcza że Paschalis II zagrożony był niemalże przez cały okres swego pontyfikatu przez opozycję wewnętrzną w Kościele oraz rosnące w siłę cesarstwo. Musiał więc koncentrować swą uwagę na ułożeniu stosunków z wieloma władcami świeckimi ${ }^{69}$. Wobec tego kwestia reformy życia duchowieństwa pojawiała się w trakcie tego pontyfikatu przede wszystkim na zgromadzeniach synodalnych, a jej śladem są zachowane teksty kanonów ${ }^{70}$. Zwróćmy jednak uwagę, że pomiędzy sferą normatywną a praktyką codzienną istniała zasadnicza różnica i papiestwo musiało

${ }^{68}$ U. R. B 1 u m e n th a l, Paschal II and the Roman Primacy, Archivum Historiae Pontificiae 16, 1978, s. 67-92; O. G u y o t j e a n n i n, Légat (Moyen Âge), w: Dictionnaire historique de la papauté, [Paris] 1994, s. 1010-1013; C. Z e y, Die Augen des Papstes. Zu Eigenschaften und Vollmachten päpstlicher Legaten, w: Römisches Zentrum (jak w przyp. 2), s. 77-108; ostatnio w ujęciu monograficznym K. R. Rennie, The foundations of Medieval Papal Legation, New York 2013, zwł. s. 154-170.

${ }^{69}$ Taki obraz pontyfikatu wyłania się z Liber pontificalis, wyd. L. Duchesne, t. II, Paris 1892, s. 296-311; zob. też R. H ü ls, Kardinäle, s. 92 n.; C. S e r v a t i u s, Paschalis II., s. 71-75, 150-155; J. Z i e s e, Wibert von Ravenna. Der Gegenpapst Clemens III (1084-1100), Stuttgart 1982 (Päpste und Papsttum 20), s. 212-274; U. R. B l u m e n t h a l, The correspondence of Pope Paschal II and Guido of Vienne 1111-1116, w: Supplementum festivum. Studies in Honour of Paul Oskar Kristeller, Binghamton 1987, s. 1-11; R. S c h w a i g e r, Pascal II, w: Dictionnaire historique de la papauté, [Paris] 1994, s. 1254-1256; R. S c h i e ffe r, Das Reformpapsttum und seine Gegenpäpste, w: Gegenpäpste. Ein unerwünschtes mittelalterliches Phänomen, Wien 2012, s. 78-82.

${ }^{70}$ U. R. B $1 \mathrm{u} \mathrm{menth}$ a l, The Early Councils of Pope Paschalis II (1100-1110), Toronto 1978, s. 10 (synod w Melfi w 1100 r.), 17-23 (synod laterański w 1102 r.), 29 n. (II synod laterański w 1105 r.), 57-65 (synod w Guastella w 1106 r.), 90-97 (synod w Troyes w 1107 r.), 103-106 (synod w Benewencie w 1108 r.), 109-122 (III synod laterański w 1110 r.). 
zdawać sobie sprawę, iż zaprowadzenie wzorców reformy gregoriańskiej (w tym wykorzenienie praktyk symoniackich i nikolaickich) będzie zadaniem, które trzeba rozłożyć na lata. Przemawia za tym również fakt, że aż do II Soboru Laterańskiego (1139) kwestia celibatu duchowieństwa nie była jednoznacznie rozstrzygnięta ${ }^{71}$. Wydaje się więc, że aby osiągnąć zamierzony cel, Paschalis II przyjął pragmatyczny sposób postępowania, dzięki czemu skutki mogły być trwalsze.

Widać to wyraźnie na przykładzie Węgier za panowania Kolomana I, kiedy to podczas obrad I synodu w Ostrzyhomiu (1100) zakazano wprawdzie dziedziczenia majątku biskupiego przez żony hierarchów i wyraźnie przykazano, aby kandydaci na biskupów nie byli żonaci, jednak nie wymagano już zachowywania celibatu od prezbiterów, a deponować nakazano tylko tych, którzy byliby konkubentami lub bigamistami $^{72}$. W żadnym z kanonów nie odnajdujemy natomiast zalecenia, aby usuwać z urzędu żonatych hierarchów, mimo że nie ma wątpliwości, iż tacy wówczas istnieli. Również w Europie Zachodniej przypadki usuwania biskupów z ich urzędu stały się o wiele rzadsze niż za pontyfikatu Grzegorza VII ${ }^{73}$. Wynikało to z faktu, że Stolica Apostolska przyjęła na początku XII w. wyraźną taktykę współdziałania władzy duchownej i świeckiej w celu reformy Kościoła, zwłaszcza w krajach położonych dalej od Rzymu (jak Anglia ${ }^{74}$ ) i/lub przez dłuższy czas nieutrzymujących z nią

71 Dokumenty soborów powszechnych, t. II, opr. A. Baron, H. Pietras SJ, Kraków 2007, s. 144-147; w szerszym ujęciu J. G a u d e m e t, Le célibat ecclésiastique. Le droit et la practique du XI ${ }^{\mathrm{e}}$ au XIII ${ }^{\mathrm{e}}$ siècle, Zeitschrift der Savigny Stiftung für Rechtgeschichte, Kanonistische Abteilung 68, 1982, s. 1-31.

72 L. Z á v o d s z k y, Szent István, Szent Lászlo és Kálmán korabeli törvények és zsinati határozatok forrásai, Budapest 1904, s. 197-207, zwł. s. 199 (kan. XI: Ut hi, qui ad episcopatum promovendi sunt, si matrimonio legitimo iuncti sunt, nisi ex consensu uxorum, non assumantur), 201 (kan. XXXI: Presbiteris uxores, quas in legitimis ordinibus acceperunt, moderacius habendas provisa fragilitate indulsimus; kan. XXXIII: Uxores episcoporum episcopalia predia non inhabitent), 204 (kan. LVI: Si quis de clero secundam uxorem vel viduam vel repudiatam duxerit deponatur; kan. LVII: Bigami presbiteri, qui ad ordines suos redire voluerint, ex consensu uxorum suarum recipiantur; kan. LVIII: Similiter, si presbiter concubinam habuerit, deponatur). O synodzie tym zob. J. R. S w e e n e y, Gregory VII, the reform program, and the Hungarian Church at the end of the Eleventh Century, Studi gregoriani per la storia della Libertas Ecclesiae 14, 1991, s. 272-275; Sz. A. S z u ro m i, Les Synodes d'Esztergom et les collectiones canonique en Hongrie au XII ${ }^{\mathrm{e}}$ siècle, w: Medieval Canon Law Collections and European Ius Commune (Középkori kánonjogi gyüjtemények és az európai ius commune), Budapest 2006, s. 32-46, zwł. s. 38-42 (tam też dalsza literatura).

${ }^{73}$ G. D e n z le r, Das Papsttum und der Amtszölibat, cz. 1, Stuttgart 1973 (Päpste und Papsttum 5/1), s. 77-79. Przykłady deponowania biskupów przytoczone przez K. S k w i e r c z y ń s k i e g o, Recepcja, s. 281, dotyczą, co warte podkreślenia, pontyfikatu Grzegorza VII, gdy możliwości działania papiestwa były zdecydowanie szersze.

${ }^{74}$ Przede wszystkim C. S e rvati u s, Zur Englandpolitik der Kurie unter Paschalis II., w: Deus qui mutat tempora. Menschen und Institutionen im Wandel des Mittelalters. Festschrift für Alfons Becker zu seinem fünfundsechzigsten Geburtstag, Sigmaringen 1987, s. 173-190, gdzie m.in. cenna uwaga (s. 183), że aż do 1107 r. najważniejsze miejsce w korespondencji pomiędzy kurią papieską a królem Anglii i tamtejszym Kościołem zajmowała kwestia inwestytury duchownych. Była to również sprawa priorytetowa na synodzie londyńskim w $1102 \mathrm{r}$. i przykuwała większą uwagę niż celibat duchownych (Councils and Synods with Other Documents Relating to the English Church, wyd. D. Whitelock, M. Brett, Ch. N. L. Brooke, t. I, Oxford 1981, s. 668-688). Por. jeszcze U. R. B l u m e n th a l, The Investiture Controversy. 
relacji (jak Polska za panowania Hermana ${ }^{75}$ ). Wypada dziś zatem w pełni podpisać się pod słowami Stanisława Smolki, który zauważył, że Gwalo „choćby żarliwym był zwolennikiem gregoriańskich idei, jął się zbytecznych środków surowości w kraju, dopiero co poddanym obediencji prawego papieża" ${ }^{\text {" }}$.

Zdecydowanie mniej uwagi $\mathrm{w}$ dotychczasowej debacie poświęcono natomiast krytycznej refleksji nad hipotezą Jadwigi Karwasińskiej, która wychodziła za założenia, że obydwaj hierarchowie zostali wyświęceni nieprawnie, stąd Gwalo musiał ich usunąć. W jej opinii ważną rolę odgrywało jednak przeświadczenie, że słynna bulla Paschalisa II o incipicie Significasti frater karissime była skierowana do Polski, dlatego uznała za fakt historyczny, że arcybiskup Marcin istotnie nie posiadał paliusza $^{77}$. Obecnie zaczyna przeważać pogląd, że adresatem papieskiej admonicji nie był arcybiskup Gniezna, lecz Splitu, Kalocsy lub Ostrzyhomia ${ }^{78}$. Chcąc zatem utrzymać w dyskusji prawdopodobny domysł J. Karwasińskiej, musimy wyprowadzić jego uzasadnienie z zupełnie innych faktów i uwarunkowań.

Zauważmy najpierw, że pierwszej przesłanki w tym względzie dostarcza nam sama bulla Significasti frater karissime, w której papież nie pozostawia wątpliwości, że traktuje posiadanie paliusza jako warunek sine qua non udzielania sakry kandydatom na biskupstwa ${ }^{79}$. Jak wynika z ponad 20 zachowanych listów i przywilejów przezeń

Church and Monarchy from the Ninth to the Twelfth Century, Philadelphia 1988, s. 142-157 (tam dalsza literatura).

${ }^{75} \mathrm{G}$. L a b u d a, Zagadnienie suwerenności Polski wczesnofeudalnej w X-XII wieku, KH 67, 1960, s. 1060 n.; A. B e c k e r, Papst Urban II. (1088-1099), t. I, Stuttgart 1964 (Schriften der MGH 19/1), s. 167 n.; K. B e n y s k i e w i c z, Książę Polski Władysław I Herman 10791102, Zielona Góra 2010, s. 309-312; A. K r a w i e c, Król bez korony, s. 166 n.

76 S. S m o 1 k a, Mieszko Stary, s. 182.

77 J. Ka rwa sińska, Archiepiscopus Polonie, s. 41-50. Starszą literaturę zebrali Z. Ko złowska-B udkowa, Repertorium, nr 22, oraz M. G ę b a rowi c z, Polska, Węgry czy Sycylia odbiorcą listu papieża Paschalisa II?, KH 51, 1937, s. 529-534 (tutaj też, s. 527-529, edycja krytyczna). Za odbiorcą polskim opowiedzieli się G. L a b u d a, List papieża Paschalisa II do niewiadomego arcybiskupa polskiego z początku XII wieku. Przyczynek do dyskusji nad faktum biskupa krakowskiego Stanisława, Śląski Kwartalnik Historyczny Sobótka 26, 1971, s. 415-434; I. S ułk ow s k a - Ku ras i ow a, S. K u rás, List Paschalisa II do arcybiskupa polskiego w świetle zasad dyplomatyki papieskiej oraz recenzji i emendacji tekstów, Roczniki Humanistyczne 34, 1986, z. 2, s. 307-318; T. J u r e k, Losy arcybiskupstwa gnieźnieńskiego w XI wieku, w: 1000 lat Archidiecezji Gnieźnieńskiej, Gniezno 2000, s. 61.

${ }^{78}$ Tak przede wszystkim M. P 1 e z i a, Dookoła sprawy św. Stanisława, Analecta Cracoviensia 11, 1979, s. 287-291; H. Ł o w m i a ń s k i, Król Bolesław II i biskup Stanisław. Dwie tendencje ustrojowe: jedynowładcza i patrymonialna, Studia Historyczne 22, 1979, s. 193196; K. S k w i e r c z y ń s k i, Recepcja, s. 147-190; P. N o w a k, Arcybiskup Polski, Splitu, Kalocsy czy Ostrzyhomia odbiorcą listu Paschalisa II: JL 6570, WH 952? [rec. z: M. Brett, Some new letters of Popes Urban II and Paschal II, Journal of Ecclesiastical History 58, 2007, s. 75-96], SŹ 45, 2007, s. 99 n. Z badaczy zagranicznych najkonsekwentniej przeciwko łączeniu wspomnianej bulli z Polską opowiedzieli się U. R. B 1 u m e n t h a 1, The Early Councils, s. 12, oraz P. Z e r b i, La „Significasti” di Pasquale II è diretta a un arcivescovo di Spalato? Riflessioni e ipotesti, w: tegoż, „Ecclesia in hoc mundo posita”. Studi di storia e di storiografia medioevale, Milano 1993, s. 73-112.

${ }^{79}$ M. G ę b a r o w i c z, Polska, s. 527: In pallio, frater, plenitudo conceditur pontificalis officii, quia iuxta sedis apostolice et totius Europe consuetudinem, ante acceptum palleum metropolitanis minime licet aut episcopos consecrare aut synodum celebrare. 
wystawionych, nie była to opinia jednorazowa ${ }^{80}$. Równie istotna mogła być ta kwestia dla samego legata, który będąc uczniem Iwona z Chartres, przejął pewnie od niego zamiłowanie do kierowania się zapisami słynnych Dekretałów Burcharda z Wormacji, w której to kolekcji przeświadczenie o niezbędności paliusza do wyświęcenia prezbiterów na biskupów jest dość wyraźnie artykułowane w dwóch kanonach ${ }^{81}$. Z potwierdzoną źródłowo walką Paschalisa II przeciwko przyjmowaniu inwestytury z rąk świeckich mamy do czynienia na bliskim chronologicznie synodzie laterańskim w 1102 r. ${ }^{82}$ Powinny nas także zainteresować źródła relacjonujące przebieg jednego z kolejnych zgromadzeń kanonicznych - synodu w Guastalla w północnych Włoszech w 1106 r. Wówczas to przybyły na zgromadzenie arcybiskup trewirski Bruno zrezygnował ze swojej godności, nie posiadał bowiem paliusza i mógł się wylegitymować jedynie inwestyturą otrzymaną z rąk króla Henryka V. Po upływie kilku dni decyzja została jednak cofnięta i Bruno mógł się cieszyć z pojednania z Paschalisem II, od którego otrzymał paliusz ${ }^{83}$. Przypadek ten, jakkolwiek kilka lat późniejszy, ukazuje z całą mocą, że na samym początku XII w. spór o inwestyturę

${ }^{80}$ Zauważył to już C. B. Graf vo n H a c k e, Die Palliumverleihungen bis 1143. Eine diplomatisch-historische Untersuchung, Marburg 1898, s. 52 n. 145 n.; zob. też R. B e n s o n, The Bishop-Elect. A Study in Medieval Ecclesiastical Office, Princeton 1968, s. 169-173. Do najnowszych ustalen S. A. S choeniga, The Papacy and the Use and Understanding of the Pallium from the Carolingians to the Early Twelfth Century (niepublikowana rozprawa Uniwersytetu Columbia 2009), podkreślających znaczenie paliusza w kanonistyce gregoriańskiej (zwł. s. 458-463) miałem dostęp tylko za pośrednictwem pracy D. A. S i k o r s k i e g o, Początki Kościoła w Polsce. Wybrane problemy, Poznań 2012, s. 285-294.

${ }_{81}$ Burchardi Wormatiensis ecclesiae episcopi decretorum libri viginti. Ergänzter Neudruck der „Editio princeps“ Köln 1548, wyd. G. Fransen, T. Kölzer, Aalen 1992, k. 3v (lib. I, can. 25), k. 29r (lib. I, can. 211). Problem recepcji Dekretałów Burcharda w kolekcjach prawa kanonicznego proweniencji niemieckiej, włoskiej i francuskiej (w tym w dziełach Iwona z Chartres) przedstawił ostatnio wyczerpująco C. R o 1 k e r, Canon Law, s. 60-81, zwł. s. 61 (gdzie bogata starsza literatura), 68-81. W polskiej literaturze zainteresowanie prawnym znaczeniem paliusza $\mathrm{w}$ dobie reformy gregoriańskiej jest marginalne; wyjątkiem są tu cenne uwagi K. S kw i er c zy ń s ki e g o, Recepcja, s. 153-155, oraz D. A. S i k or ski e g o, Początki Kościoła, zwł. s. 292-296.

82 Zestawienie źródeł u U. R. B 1 u m e n th a l, Early Councils, s. 17-23.

${ }^{83}$ Gesta Treverorum, wyd. G. Waitz, MGH Scriptores, t. VIII, Hannoverae 1848, s. 192: honorifice inquam susceptus [Bruno], sed quoniam episcopalia, anulum videlicet et baculum, per manum laicam suscepisset, atque quia ecclesias dedicasset et clericos necdum pallium consecutus promovisset, multum aspere correptus est, et decernente episcoporum ibi congregatorum concillio, pontificatus officium deposuit, quod tamen eisdem intervenientibus, quia discrecio eius et prudentia officio et tempori conveniens erat, post triduum non sine admissorum penitentia recuperavit. Iniuncta est autem ei penitentia, ut quociens in spacio trium proximorum annorum missarum sollempia celebraret, dalmatica non uteretur; quod ipse humiliter inplevit. Deinde accepta tam apostolici quam totius sinodi benedictione, pallii honore donatus, atque de regula fidei firmiter observanda instructus, atque de instructione commissi sibi gregis dilligenter admonitus, in sua cum gaudio remeavit. O licznych depozycjach biskupów z Rzeszy oraz jednego z Italii za przyjęcie inwestytury z rąk świeckich mówi ważna zapiska w Annales Patherbrunenses, wyd. P. Scheffer-Boichorst, Innsbruck 1870, s. 116: Plures ibi episcopi Italiae damnantur, quidam anathemizantur. Patriarcha Aquileiae anathemizatur, Fridericus Halverstatensis, accusantibus eum ecclesiae canonicis, honore episcopali privatur. Similis sententia de Widelone Mindensi habetur. Leodicensis et Cameracensis anathemizantur. Szerzej zob. U. R. B l u m e n th a 1, Some notes on papal policies at Guastalla, 1106, Studia Gratiana 19, 1976, s. 65-68. 
z rąk świeckich wchodził w decydujące stadium, a papieskie żądanie posiadania paliusza było coraz mocniej artykułowane.

Zadając zatem pytanie o przyczynę depozycji dwóch hierarchów polskiego Kościoła, powinniśmy uwzględnić powyższe analogie, które zdają się sugerować, że za hipotezą J. Karwasińskiej stoją silne, choć przez nią niewyartykułowane, racje. Gwalo, przybywszy nad Wisłę i zorientowawszy się w składzie personalnym polskiego episkopatu, mógł uznać, że dwaj ordynariusze otrzymali święcenia nieprawnie. Pozostanie oczywiście wątpliwość, dlaczego nie usunął również samego arcybiskupa gnieźnieńskiego, o którym nie wiemy, aby posiadał paliusz ${ }^{84}$. Być może Paschalis II, powiadomiony przez Baldwina o kłopotach Kościoła w Polsce (fidei ruditatem intimavit), przez ręce Gwalona przysłał Marcinowi brakujący paliusz, co uratowało go od groźby depozycji. Nawet jednak gdyby Marcin nie został w 1103 r. obdarowany paliuszem, to i tak mógł, jak sądzimy, w drodze wyjątku pozostać na swoim stanowisku ze względu na podział państwa na dwa władztwa (Zbigniewa i Bolesława), które on - jako zwierzchnik prowincji kościelnej i zarazem mediator w konflikcie między braćmi - mógł zachować od całkowitego rozdziału. Są to jednak tylko hipotezy, których nie da się podeprzeć niczym więcej, jak tylko intuicją i wewnętrzną logiką.

\section{LEGACJA GWALONA A POCHODZENIE POLSKICH EGZEMPLARZY TZW. TRIPARTITY}

W literaturze spotkać można nieraz artykułowane przez badaczy przekonanie, że legacja Gwalona była wprawdzie tylko epizodem w dziejach stosunków Polski ze Stolicą Apostolską, jednak trwałość reform zaprowadzonych w polskim Kościele na synodzie 1103 r. miała zostać wzmocniona przywiezieniem przez legata egzemplarza Tripartity - kolekcji prawa kanonicznego przypisywanej Iwonowi z Chartres ${ }^{85}$. Jako pierwszy pogląd ten wprowadził Tadeusz Silnicki, a akces do jego ustaleń zgłosili następnie liczni autorzy, począwszy od Pierre'a Davida aż po Krzysztofa Skwierczyńskiego ${ }^{86}$. Fundamentem omawianej hipotezy stała się obecność w polskich zbiorach dwóch dwunastowiecznych egzemplarzy Tripartity, które miałyby zostać przepisane w skryptoriach krakowskim i gnieźnieńskim na podstawie rękopisu Gwalonowego ${ }^{87}$.

${ }^{84}$ K. R. P r o k o p, Arcybiskupi gnieźnieńscy w tysiącleciu, Kraków 2000, s. 33-38; por. J. D o b o s z, Monarcha i możni, s. 175-178, 225 n. (tam zestawienia literatury).

${ }^{85} \mathrm{O}$ kolekcji tej szerzej L. Kérry, Canonical Collections of the Early Middle Ages (c. 400-1140). A Biographical Guide to the Manuscripts and Literature, Washington D.C., 1999 , s. $244-260$.

${ }^{86}$ T. S i ln i c ki, Wpływy francuskie na Kościół w Polsce w wiekach średnich, Przegląd Teologiczny 7, 1926, s. 50, 55-59 (przedruk w: tegoż, Z dziejów Kościoła w Polsce. Studia i szkice historyczne, Warszawa 1960, s. 400 n., 427-435); P. D a vi d, Un disciple, s. 109-113; por. też J. S z y m a ń s k i, Krakowski rękopis reguły akwizgrańskiej z roku około 1103, SŹ 11, 1966, s. 39-52, zwł. s. 41-44; K. S k w i e r c z y ń s ki, Recepcja, s. 262-265; bardzo bogate omówienie dyskusji dał ostatnio P. N o w a k, Legacja Galona, s. 431-433.

87 Kraków, Archiwum i Biblioteka Krakowskiej Kapituły Katedralnej, sygn. MS KP 84; Gniezno, Archiwum Archidiecezjalne, Biblioteka Katedralna, sygn. MS 25. Na temat obydwu rękopisów por. ostatnio P. N ow a k, The manuscripts of the Collectio Tripartita in Poland, w: Bishops, Texts and the Use of Canon Law round 1100. Essays in Honour of Martin Brett, Aldershot 2008, s. 91-110 (gdzie starsza literatura). 
Z najnowszych studiów Martina Bretta oraz Przemysława Nowaka wynika jednak coś zgoła przeciwnego. Obydwa polskie manuskrypty nie posiadały mianowicie wspólnego archetypu. Tripartita gnieźnieńska wykazuje bowiem łączność z tradycją rękopiśmienną tego zabytku z terenów południowoniemieckich, natomiast egzemplarz krakowski - z tradycją normandzką (rejon Fécamp) bądź austriacką (rejon Vorau w Styrii) ${ }^{88}$. Co więcej, gdyby przyjrzeć się dokładnie inwentarzowi skarbca i biblioteki kapituły krakowskiej z 1110 r., widać, że figurujące wśród ksiąg capitulare nie musi być utożsamiane z rękopisem Tripartity, jak powszechnie dotąd przyjmowano. Ten ostatni jest bowiem spisanym co najmniej jedenastoma rękami kodeksem o bardzo różnej treści, a w jego skład wchodzą, oprócz Collectio trium partium w redakcji średniej (niepełnej), także Institutio canonicorum Aquisgranensis, Martyrologium Bedae Venerabilis, Ordines Romanae ecclesiae i dwa wspominane już wyżej inwentarze datowane na 1101 i 1110 r. Słowo capitulare, jak podkreśla P. Nowak, nie było zazwyczaj używane na oznaczenie kolekcji kanonów, lecz raczej ksiąg liturgicznych, co może stanowić istotny argument przeciwko tezie, że krakowski rękopis znajdował się już w 1110 r. na Wawelu ${ }^{89}$. Dokładniejsza datacja jego pojawienia się w stolicy Małopolski wymaga jednak dalszych badań. Nie zmienia to wszakże faktu, że obydwa manuskrypty nie miały - jak się okazuje - wspólnego archetypu i reprezentują odmienne stadia redakcji, co sprawia, że do prób łączenia ich obu z osobą Gwalona trzeba zachować stosowny dystans. Konsekwencje tego stwierdzenia są jednak dużo poważniejsze.

Zauważmy bowiem, że wraz z nim traci ostatni fundament źródłowy hipoteza, że legat papieski w ogóle wprowadzał jakieś szersze reformy w Kościele polskim. Nie możemy wykluczyć, że jedynym polem jego działalności było doraźne uporządkowanie kwestii obsady personalnej dwóch polskich biskupstw, co zapisano w źródłach. Ponadto gdyby zdecydował się on na próbę nawet powierzchownego zaszczepienia w Polsce zalążków reformy gregoriańskiej, to można byłoby oczekiwać na jakąś formę dalszego zainteresowania papiestwa państwem Bolesława Krzywoustego. Po dość gruntownej krytyce poglądu na temat polskiego adresata bulli Significasti frater karissime, jaką w wielu punktach uznajemy za przekonującą, nie widzimy żadnych śladów późniejszych kontaktów Polski z papiestwem za pontyfikatu Paschalisa II. Znamienna jest tu zwłaszcza całkowita absencja Polski w źródłach rzymskich, które z początku XII w. zachowały się już dość licznie. W efekcie widać dziś jeszcze dobitniej niż dawniej, że pierwsze wzmianki o szerszym zainteresowaniu papiestwa sprawami polskimi dotyczą dopiero lat czterdziestych XII w., kiedy to w obrębie zaledwie jednej dekady mamy potwierdzone źródłowo trzy legacje ${ }^{90}$, a zatem tylko o jedną mniej w porównaniu z okresem ponad 140 lat, począwszy od roku 1000.

${ }^{88}$ Te n że, Die polnische Kirchenprovinz, s. 197 n.; t e n ż e, The Manuscripts, s. 91-99; t e n ż e, Legacja Galona, s. 433 (gdzie ogólnie hipoteza o pochodzeniu północnofrancuskim).

${ }^{89} \mathrm{Te}$ e że, The Manuscripts, s. 98.

${ }^{90}$ Chodzi o wizyty w Polsce: 1) anonimowego legata, który uczestniczył w konsekracji katedry wawelskiej w 1142 r. i przyznał z tej okazji 40 dni odpustu (Kalendarz katedry krakowskiej, MPH SN V, s. 141, pod 12 IV 1142 r.); 2) Humbalda z 1145/1146 r.; 3) Gwidona z Cremony z 1148/1149 r. Na temat dwóch ostatnich zob. S. W e i ß, Die Urkunden, s. 155 n., 161-163. 


\section{REKAPITULACJA}

Wnioski z naszej analizy zebrać można w następujących punktach:

1) Legacja Gwalona biskupa elekta Beauvais, a następnie biskupa Paryża, do Polski odbyła się najpewniej wiosną (kwiecień/maj?) 1103 r., którą to datę roczną odnajdujemy w dwóch redakcjach Rocznika małopolskiego (z kodeksu Kuropatnickiego i lubińskiego) oraz w Roczniku Sędziwoja. Pojawiające się w innych przekazach daty: 1105 (Rocznik małopolski z kodeksu królewieckiego) oraz 1104 (Rocznik kapituły krakowskiej) nie wydają się właściwe w konfrontacji z przekazami proweniencji niepolskiej.

2) Sekwencję wydarzeń z przełomu 1102 i 1103 r., bezpośrednio poprzedzających przyjazd Gwalona do Polski, najpełniej oddaje Kronika Galla Anonima (II 23-27). Kolejność ta znajduje też całkowite potwierdzenie w chronologii bezwzględnej przekazanej przez źródła zagraniczne.

3) Poszukując w polskim episkopacie początku XII w. dwóch hierarchów usuniętych z godności przez legata, opowiadamy się za zdaniem mniejszości badaczy, uznających, że byli to nieznani imiennie biskupi poznański i płocki. Wiemy bowiem, że nie zmieniła się obsada biskupstwa wrocławskiego (Piotr ordynowany w 1074, zmarły w 1111/1112 r.) oraz krakowskiego (Baldwin uzyskał konsekrację w Rzymie przed legacją Gwalona, a zmarł w 1109 r.). Domysł o depozycji Czasława krakowskiego, sformułowany już przez Długosza, jest nie do przyjęcia. Czasław mógł dobrowolnie ustąpić z urzędu, a może umrzeć przed konsekracją lub krótko po niej. Brak wzmianek o nim w źródłach przeddługoszowych nie może być traktowany jako dowód zapadłej w jego sprawie damnatio memoriae.

4) Za najbardziej prawdopodobną przyczynę akcji depozycyjnej podjętej przez Gwalona należy uznać okoliczność, że owi dwaj anonimowi hierarchowie zostali wyświęceni przez arcybiskupa nieposiadającego paliusza, stąd ich sakra została uznała za nieważną. Za takim rozwiązaniem przemawiają liczne analogie z tego czasu. Przeciwko konkurencyjnemu poglądowi o usunięciu biskupów za nikolaityzm świadczy zaś przede wszystkim fakt, że w zachowanych dokumentach legatów nie odnajdujemy żadnych dowodów na to, aby papiestwo prowadziło wówczas przez nich szerszą akcję mającą na celu ukrócenie praktyki zawierania małżeństw przez duchownych. Pytanie, dlaczego Gwalo nie zdeponował również arcybiskupa gnieźnieńskiego, o którym nie wiadomo, aby posiadał paliusz, musi pozostać bez jednoznacznej odpowiedzi. Prawdopodobnie jednak uczyniono tu wyjątek ze względu na niepewną sytuację polityczną kraju podzielonego między skłóconych braci.

5) Przychylamy się do poglądu Przemysława Nowaka, że Gwalo nie przywiózł ze sobą do Polski egzemplarza tzw. Tripartity, gdyż dwa dwunastowieczne polskie rękopisy tej kolekcji kanonów reprezentują odmienne redakcje i nie miały wspólnego archetypu.

6) Przy obecnym stanie zachowania źródeł nowe ustalenia może przynieść jedynie szersza analiza pryncypiów papieskiej polityki wobec krajów chrześcijańskiego świata na przełomie XI i XII w. Byłoby to skądinąd ważkie zadanie dla całej historiografii, a ,do ujęcia tego tematu praca niniejsza chce być skromnym, bo z pod pióra niedoświadczonego historyka wychodząca, lecz pobudzającym przyczynkiem"91.

${ }^{91}$ G. L a b u d a, Polska i krzyżacka misja w Prusach do początku XIII w., Annales Missiologicae 9, 1937, s. 428. 


\section{BIBLIOGRAFIA}

Abraham W., Organizacja Kościoła w Polsce do połowy wieku XII, wyd. 4, Wodzisław Śląski 2009.

Abraham W., Początek biskupstwa i kapituły katedralnej w Krakowie, Rocznik Krakowski 4, 1900.

Annales Patherbrunenses, wyd. P. Scheffer-Boichorst, Innsbruck 1870.

Anonim tzw. Gall, Kronika polska, tłum. R. Grodecki, Kraków 1923; tłum. R. Grodecki, opr. M. Plezia, Wrocław 2003.

Balzer O., Genealogia Piastów, wyd. 2, Kraków 2005.

Baran-Kozłowski W., Arcybiskup gnieźnieński Henryk Kietlicz (1199-1219), Poznań 2005.

Becker A., Papst Urban II. (1088-1099), t. I, Stuttgart 1964 (Schriften der MGH 19/1).

Benson R., The Bishop-Elect. A Study in Medieval Ecclesiastical Office, Princeton 1968.

Benyskiewicz K., Książę Polski Władysław I Herman 1079-1102, Zielona Góra 2010.

Beulertz S., Das Verbot der Laieninvestitur im Investiturstreit, Hannover 1991 (MGH Studien und Texte 2).

Bieniak J, Autor Rocznika dawnego, w: Kultura średniowieczna i staropolska. Studia ofiarowane Aleksandrowi Gieysztorowi w pięćdziesięciolecie pracy naukowej, Warszawa 1991.

Birkenmajer A., Nowy katalog biskupów wrocławskich, w: Studia historyczne ku czci Stanisława Kutrzeby, t. II, Kraków 1938.

Blet P., Histoire de la répresentation diplomatique du Saint Siège des origines à l'aube du XIX ${ }^{\mathrm{e}}$ siècle, Città del Vaticano 1982.

Blumenthal U. R., Paschal II and the Roman Primacy, Archivum Historiae Pontificiae 16, 1978.

Blumenthal U. R., Some notes on papal policies at Guastalla, 1106, Studia Gratiana 19, 1976.

Blumenthal U. R., The correspondence of Pope Paschal II and Guido of Vienne 1111-1116, w: Supplementum festivum. Studies in Honour of Paul Oskar Kristeller, Binghamton 1987.

Blumenthal U. R., The early councils of Pope Paschalis II (1100-1110), Toronto 1978.

Blumenthal U. R., The Investiture Controversy. Church and Monarchy from the Ninth to the Twelfth Century, Philadelphia 1988.

Borkowska U. OSU, Odbudowa i rozwój (2. poł. XI i XII w.), w: Chrześcijaństwo w Polsce. Zarys przemian 966-1979, Lublin 1992.

Burchardi Wormatiensis ecclesiae episcopi decretorum libri viginti. Ergänzter Neudruck der „Editio princeps” Köln 1548, wyd. G. Fransen, T. Kölzer, Aalen 1992.

Canonical Collections of the Early Middle Ages (c. 400-1140). A Biographical Guide to the Manuscripts and Literature, Washington D.C., 1999.

Chronica Alberici monachi Trium Fontium, wyd. P. Scheffer-Boichorst, Monumenta Germaniae historica, Scriptores, t. XXIII, Hannoverae 1874.

Cosmae Pragensis Chronica Boemorum, wyd. B. Bretholz, Monumenta Germaniae historica, Scriptores rerum Germanicarum, nova series, t. II, Berlin 1923.

Councils and Synods with other Documents relating to the English Church, wyd. D. Whitelock, M. Brett, Ch. N. L. Brooke, t. I, Oxford 1981.

David P., Un disciple d'Yves de Chartres en Pologne - Galon de Paris et le droit canonique, w: La Pologne au VII ${ }^{\mathrm{e}}$ Congrés International des scientes historiques, t. I, Varsovie 1933.

Denzler G., Das Papsttum und der Amtszölibat, cz. 1, Stuttgart 1973 (Päpste und Papsttum 5/1).

Depoin J., Essai sur la chronologie des évêques de Paris de 768 à 1138, Bulletin historique et philologique du Comité des travaux historiques et scientifiques 24, 1906.

Die Regesten der Bischöfe und des Domkapitels von Bamberg, opr. E. von Guttenberg, Würzburg 1963 (Veröffentlichungen für fränkische Geschichte, VI Reihe).

Dobosz J., Monarcha i możni wobec Kościoła w Polsce do początku XIII wieku, Poznań 2002.

Dokumenty soborów powszechnych, t. II, opr. A. Baron, H. Pietras SJ, Kraków 2007.

Drelicharz W., Annalistyka małopolska XIII-XV wieku. Główne kierunki rozwoju wielkich roczników kompilowanych, Kraków 2003. 
Drelicharz W., Idea zjednoczenia królestwa w średniowiecznym dziejopisarstwie polskim, Kraków 2012.

Dumont C., L' abbaye de Saint-Quentin de Beauvais (XI'-XIII ${ }^{\mathrm{e}}$ siècles), Positions des thèses soutenues par les élèves de la promotion de 1991 pour obtenir le diplôme d'archiviste-paléographe. Ecole Nationale des Chartres.

Eadmeri monachi Cantuariensis Vita sancti Anselmi archiepiscopi Cantuariensis (The Life of St Anselm by Eadmer), wyd. R. W. Southern, London 1962.

Ebonis Vita s. Ottonis, wyd. J. Wikarjak, K. Liman, Monumenta Poloniae historica, series nova, t. VII, cz. 2, Warszawa 1969.

Epistolae Ivonis Carnotensis episcopi, wyd. M. J. Brial, w: Recueil des historiens des Gaules et de la France, t. XV, Paris 1878.

Epistolae Paschalis II papae, wyd. M. J. Brial, w: Recueil des historiens des Gaules et de la France, t. XV, Paris 1878.

Fliché A., Le règne de Philippe $\mathrm{I}^{\mathrm{er}}$, roi de France (1060-1108), Paris 1912.

Galli Anonymi Cronicae et gesta ducum sive prinicipum Polonorum, wyd. K. Maleczyński, Monumenta Poloniae historica, series nova, t. II, Cracoviae 1952.

Gąsiorowski A., Paweł, w: Słownik starożytności słowiańskich, t. IV, Wrocław 1970.

Gaudemet J., Le célibat ecclésiastique. Le droit et la practique du XI ${ }^{\mathrm{e}}$ au XIII ${ }^{\mathrm{e}}$ siècle, Zeitschrift der Savigny Stiftung für Rechtgeschichte. Kanonistische Abteilung 68, 1982.

Gębarowicz M., Polska, Węgry czy Sycylia odbiorcą listu papieża Paschalisa II?, Kwartalnik Historyczny 51, 1937.

Gębarowicz M., Walo, biskup Beauvais i Paryża i jego legacyja w Polsce, Sprawozdania Towarzystwa Naukowego we Lwowie 3, 1923.

Gesta Treverorum, wyd. G. Waitz, Monumenta Germaniae historica, Scriptores, t. VIII, Hannoverae 1848 .

Gieysztor A., Bamberg i Polska w XI i XII wieku, Studia Źródłoznawcze 15, 1971.

Gieysztor A., O kilku biskupach polskich XI wieku, w: Europa - Słowiańszczyzna - Polska. Studia ku uczczeniu profesora Kazimierza Tymienieckiego, Poznań 1970.

Gieysztor A., Przemiany ideologiczne w państwie pierwszych Piastów a wprowadzenie chrześcijaństwa, w: Początki państwa polskiego. Księga Tysiąclecia, t. II, Poznań 1962.

Graf von Hacke C. B., Die Palliumverleihungen bis 1143. Eine diplomatisch-historische Untersuchung, Marburg 1898.

Grodecki R., Baldwin, w: Polski słownik biograficzny, t. I, Kraków 1935.

Grodecki R., Czasław, w: Polski słownik biograficzny, t. IV, Kraków 1938.

Güttner-Sporzyński D. von, Poland and the Papacy before the Second Crusade, w: La papauté et les crosaides, Farnheim 2011.

Guyotjeannin O., Légat (Moyen Âge), w: Dictionnaire historique de la papauté, [Paris] 1994.

Hiestand R., Les légats pontificaux en France du milieu XI ${ }^{\mathrm{e}}$ à la fin du XII ${ }^{\mathrm{e}}$ siècle, w: L'Église de France et la papauté ( $\mathrm{X}^{\mathrm{e}}-\mathrm{XIII} \mathrm{I}^{\mathrm{e}}$ siècle). Die französische Kirche und das Papsttum (10.-13. Jahrhundert), Paris 1993.

Hüls R., Kardinäle, Klerus und Kirchen Roms 1049-1130, Tübingen 1977.

Ioannis Dlugossii Annales seu cronicae incliti Regni Poloniae, lib. III-IV, Varsaviae 1970.

Ioannis Dlugossii Vitae episcoporum Plocensium abbreviatae cum continuatione Laurentii de Wszerecz, wyd. W. Kętrzyński, Monumenta Poloniae historica, t. VI, Kraków 1893.

Jana Długosza Roczniki, czyli kroniki sławnego Królestwa Polskiego, ks. III-IV, tłum. J. Mrukówna, Warszawa 1969.

Jasiński K., Najstarsze roczniki krakowskie, Kwartalnik Historyczny 88, 1981.

Jasiński K., Rodowód pierwszych Piastów, Warszawa-Wrocław [1992].

Jurek T., Losy arcybiskupstwa gnieźnieńskiego w XI wieku, w: 1000 lat Archidiecezji Gnieźnieńskiej, Gniezno 2000.

Jurek T., Ryczyn biskupi. Studium z dziejów Kościoła polskiego w XI w., Roczniki Historyczne $60,1994$. 
Jurek T., Zagadka biskupa wrocławskiego Roberta, Śląski Kwartalnik Historyczny Sobótka 45, 1990.

Kalendarz katedry krakowskiej, wyd. Z. Kozłowska-Budkowa, Monumenta Poloniae historica, series nova, t. V, Warszawa 1978.

Kalinowski L., Najstarsze inwentarze skarbca katedry krakowskiej jako źródło do dziejów sztuki w Polsce, w: Cultus et cognitio. Studia z dziejów średniowiecznej kultury, Warszawa 1976.

Karwasińska J., Archiepiscopus Polonie - archiepiscopus Gneznensis. O adresacie bulli Paschalisa II, Studia Źródłoznawcze 27, 1983.

Katalogi biskupów krakowskich, wyd. J. Szymański, Monumenta Poloniae historica, series nova, t. X/2, Warszawa 1974.

Katalogi biskupów wrocławskich, wyd. W. Kętrzyński, Monumenta Poloniae historica, t. VI, Lwów 1893.

Kodeks dyplomatyczny Wielkopolski, t. I, [wyd. I. Zakrzewski], Poznań 1877.

Korta W., Sredniowieczna annalistyka śląska, Wrocław 1966.

Korytkowski J. ks., Arcybiskupi gnieźnieńscy, prymasowie Polski i metropolici polscy od roku 1000 aż do roku 1821, t. I, Poznań 1888.

Kosmasa Kronika Czechów, opr. M. Wojciechowska, wyd. 3, Wodzisław Śląski 2012.

Kosonowski M., Dokumenty księżnej Salomei i księcia Mieszka Starego dla klasztoru benedyktynów w Mogilnie z XVII-wiecznego kopiariusza Archiwum Krakowskiej Kapituły Katedralnej. Studium krytyczne i edycja tekstu, w: Signa. Studia i szkice z nauk pomocniczych historii. Prace dedykowane Profesorowi Zenonowi Piechowi w sześćdziesiątą rocznicę urodzin, Kraków 2014.

Kosonowski M., Postać i panowanie Bolesława Krzywoustego w nowym historiograficznym ujęciu. Kilka uwag o pracy Stanisława Rosika „Bolesław Krzywousty”, Studia Historyczne 57, 2014.

Kozłowska-Budkowa Z., Który Bolesław?, w: Prace z dziejów Polski feudalnej ofiarowane Romanowi Grodeckiemu w 70. rocznicę urodzin, Warszawa 1960.

Kozłowska-Budkowa Z., Repertorium polskich dokumentów doby piastowskiej, wyd. 2, Kraków 2006.

Kozłowska-Budkowa Z., Wstęp, do: Monumenta Poloniae historica, series nova, t. V, Warszawa 1978.

Krawiec A., Król bez korony. Władysław I Herman, książę polski, Warszawa 2014.

Kronika książąt polskich, wyd. Z. Węclowski, Monumenta Poloniae historica, t. III, Lwów 1878.

Labuda G., Arcybiskup Henryk - arcybiskup Bogumił - arcybiskup Bogumił-Piotr, w: tegoż, Szkice historyczne X-XI wieku. Z dziejów organizacji Kościoła w Polsce we wczesnym średniowieczu, Poznań 2004.

Labuda G., Dyplomacja polska wczesnego feudalizmu (wiek X - 1306 r.), w: Historia dyplomacji polskiej, t. I, Warszawa 1982.

Labuda G., Katalogi biskupów krakowskich przed Długoszem, Studia Źródłoznawcze 27, 1983.

Labuda G., List papieża Paschalisa II do niewiadomego arcybiskupa polskiego z początku XII wieku. Przyczynek do dyskusji nad faktum biskupa krakowskiego Stanisława, Śląski Kwartalnik Historyczny Sobótka 26, 1971.

Labuda G., Początki diecezjalnej organizacji kościelnej na Pomorzu i na Kujawach w XI i XII wieku, Zapiski Historyczne 33, 1968.

Labuda G., Polska i krzyżacka misja w Prusach do początku XIII w., Annales Missiologicae 9, 1937.

Labuda G., Roczniki polskie, w: Słownik starożytności słowiańskich, t. IV, Wrocław 1970.

Labuda G., Zagadnienie suwerenności Polski wczesnofeudalnej w X-XII wieku, Kwartalnik Historyczny 67, 1960.

Lec Z., Wiadomości o pierwszych biskupach śląskich w świetle kroniki Thietmara i niektórych wrocławskich katalogów biskupich, Śląski Kwartalnik Historyczny Sobótka 53, 1998. 
Liber pontificalis, wyd. L. Duchesne, t. II, Paris 1892.

Luchaire A., Louis VI le Gros. Annales de sa vie et de son règne (1081-1137), Paris 1890.

Łowmiański H., Król Bolesław II i biskup Stanisław. Dwie tendencje ustrojowe: jedynowładcza i patrymonialna, Studia Historyczne 22, 1979.

Łowmiański H., Początki Polski, t. VI, cz. 1, Warszawa 1985.

Małecki A., W kwestii fałszerstwa dokumentów, Kwartalnik Historyczny 18, 1904.

Maleczyński K., Bolesław III Krzywousty, wyd. 2, Kraków 2010.

Maleczyński K., rec. z: Z. Kozłowska-Budkowa, Repertorium polskich dokumentów doby piastowskiej, z. 1, Kraków 1937, Kwartalnik Historyczny 51, 1937.

Maleczyński K., W sprawie nieznanego biskupa polskiego Henryka z XI wieku, Sprawozdania Towarzystwa Naukowego we Lwowie 17, 1937.

Mansi J. D., Sacrorum concilliorum nova et amplissima collectio, t. XX, Venetiis 1775.

Michalski M., Ustanowienie i wczesne dzieje biskupstwa kujawskiego, w: Scripta minora, t. I, Poznań 1996.

Monod B., Essai sur les rapports de Pascal II avec Philippe Ir: 1099-1118, Paris 1907.

Monod B., L'Eglise et l'Etat au XII" siècle. L'élection épiscopale de Beauvais de 1100 à 1104. Etienne de Garlande et Galon, Mémoires de la Société Académique d'Archéologie du Département de l'Oise 19, 1904/1906.

Naruszewicz A., Historia narodu polskiego od początku chrześcijaństwa, t. III, Warszawa 1781.

Necrologium monasterii S. Emmeramii Ratisbonensis, wyd. F. L. Baumann, Monumenta Germaniae historica, Necrologia, t. III, Berolini 1905.

Necrologium Weltenburgense, wyd. F. L. Baumann, Monumenta Germaniae historica, Necrologia, t. III, Berolini 1905.

Nowacki J. ks., Dzieje archidiecezji poznańskiej, t. I, Poznań 1958.

Nowak P., Arcybiskup Polski, Splitu, Kalocsy czy Ostrzyhomia odbiorcą listu Paschalisa II: JL 6570, WH 952? [rec. z: M. Brett, Some new letters of Popes Urban II and Paschal II, Journal of Ecclesiastical History 58, 2007, s. 75-96], Studia Źródłoznawcze 45, 2007.

Nowak P., Das Papsttum und Ostmitteleuropa (Böhmen-Mähren, Polen, Ungarn) vom ausgehenden 10. bis zum Beginn 13. Jahrhunderts, w: Rom und die Regionen. Studien zur Homogenisierung der lateinischen Kirche im Hochmittelalter, Berlin 2012.

Nowak P., Die polnische Kirchenprovinz Gnesen und die Kurie im 12. Jahrhundert, w: Römisches Zentrum und kirchliche Peripherie. Das universale Papsttum als Bezugspunkt der Kirchen von den Reformpäpsten bis zu Innocenz III., Berlin 2008.

Nowak P., Legacja Galona, biskupa-elekta Beauvais do Polski w 1104 roku i Collectio tripartita, Przegląd Historyczny 105, 2014.

Nowak P., The Manuscripts of the Collectio Tripartita in Poland, w: Bishops, Texts and the Use of Canon Law around 1100. Essays in Honour of Martin Brett, Aldershot 2008.

Nowakowski T., Źródła Jana Długosza do dziejów Mazowsza w XI-XIV wieku. W poszukiwaniu rocznika płockiego, Bydgoszcz 2012.

Obituaire de la cathédrale Notre-Dame de Paris, wyd. A. Molinier, w: Obituaires de la province de Sens, t. I: Dioèceses de Sens et de Paris, Paris 1902.

Ożóg K., Robert, w: Polski słownik biograficzny, t. XXXI, Wrocław 1988.

Papsturkunden in Frankreich (Neue Folge), wyd. J. Ramackers, t. III: Artois, Göttingen 1940.

Plezia M., Dookoła sprawy św. Stanisława, Analecta Cracoviensia 11, 1979.

Plezia M., Księgozbiór katedry krakowskiej wedle inwentarza z r. 1110, w: Silva rerum. Series nova, wychodzi jak jest gotowa..., Kraków 1981.

Polonia Pontificia, sive Repertorium privilegiorum et litterarum a Romanis pontificis ante annum MCLXXXXVIII Poloniae ecclesiis, monasteriis, civitatibus, singulisque personis concessorum, opr. W. Könighaus (Regesta pontificum Romanorum), Gottingae 2014.

Potkowski E., Fiktive Biographien in den Katalogen polnischer Bischöfe des Jan Długosz, w: Fälschungen im Mittelalter, t. I, Hannover 1988.

Повесть временных леt, wyd. Д. С. Лихачёв, t. I, Москва 1950. 
Powieść minionych lat. Najstarsza kronika kijowska, opr. F. Sielicki, Wodzisław Śląski 2014. Prokop K. R., Arcybiskupi gnieźnieńscy w tysiącleciu, Kraków 2000.

Rennie K. R., The foundations of Medieval Papal Legation, New York 2013.

Rocznik dawny, wyd. Z. Kozłowska-Budkowa, Monumenta Poloniae historica, series nova, t. V, Warszawa 1978.

Rocznik kamieniecki, wyd. A. Bielowski, Monumenta Poloniae historica, t. II, Lwów 1872.

Rocznik kapituły krakowskiej, wyd. Z. Kozłowska-Budkowa, Monumenta Poloniae historica, series nova, t. V, Warszawa 1978.

Rocznik małopolski, wyd. A. Bielowski, Monumenta Poloniae historica, t. III, Lwów 1878.

Rocznik Sędziwoja, wyd. A. Bielowski, Monumenta Poloniae historica, t. II, Lwów 1872.

Rocznik świętokrzyski, wyd. A. Rutkowska-Płachcińska, Monumenta Poloniae historica, series nova, Kraków 1996.

Rolker C., Canon Law and the Letters of Ivo of Chartres, Cambridge 2009.

Rosik S., Bolesław Krzywousty, Wrocław 2013.

Schieffer R., Das Reformpapsttum und seine Gegenpäpste, w: Gegenpäpste. Ein unerwünschtes mittelalterliches Phänomen, Wien 2012.

Schieffer T., Die päpstlichen Legaten in Frankreich vom Vertrage von Meersen (870) bis zum Schisma von 1130, Berlin 1935.

Schmidt O., Untersuchungen zu den Breslauer Bischofskatalogen, Breslau 1917.

Schuchard Ch., Päpstliche Legaten und Kollektoren nördlich der Alpen, w: Kommunikation und Möbilitat im Mittelalter. Begegnungen zwischen dem Süden und der Mitte Europas (11. bis 14. Jahrhundert), Sigmaringen 1995.

Schulte F., Zu den Breslauer Bischofskatalogen, Zeitschrift für Geschichte Schlesiens 44, 1910.

Schumann O., Die päpstlichen Legaten in Deutschland zur Zeit Heinrichs IV. und Heinrichs V. (1056-1125), Marburg 1912.

Schwaiger R., Pascal II, w: Dictionnaire historique de la papauté, [Paris] 1994.

Semkowicz W., Rocznik tzw. świętokrzyski dawny, Rozprawy Polskiej Akademii Umiejętności, Wydział Historyczno-Filozoficzny 53, 1910.

Servatius C., Paschalis II. (1099-1118), Stuttgart 1979 (Päpste und Papsttum 14).

Servatius C., Zur Englandpolitik der Kurie unter Paschalis II., w: Deus qui mutat tempora. Menschen und Institutionen im Wandel des Mittelalters. Festschrift für Alfons Becker zu seinem fünfundsechzigsten Geburtstag, Sigmaringen 1987.

Sikorski D. A., Początki Kościoła w Polsce. Wybrane problemy, Poznań 2012.

Silnicki T., Dzieje i ustrój Kościoła katolickiego na Śląsku do końca w. XIV, Warszawa 1953.

Silnicki T., Z dziejów Kościoła w Polsce. Studia i szkice historyczne, Warszawa 1960.

Skwierczyński K., Recepcja idei gregoriańskich w Polsce do początku XIII wieku, Wrocław 2005.

Smolka S., Mieszko Stary i jego wiek [1881], wyd. 3, Kraków 2009.

Southern R. W., Saint Anselm and his Biographer. A Study of Monastic Life and Thought 1059 - ca. 1130, Cambridge 1963.

Spisy dawne skarbca i inwentarza skarbca i biblioteki kapitulnej krakowskiej, wyd. A. Bielowski, Monumenta Poloniae historica, t. I, Lwów 1864.

Sprandel R., Ivo von Chartres und seine Stellung in der Kirchengeschichte, Stuttgart 1962.

Strzelczyk J., Bamberg a Polska w średniowieczu, Roczniki Historyczne 62, 1996.

Sułkowska-Kurasiowa I., Kuraś S., List Paschalisa II do arcybiskupa polskiego w świetle zasad dyplomatyki papieskiej oraz recenzji i emendacji tekstów, Roczniki Humanistyczne 34, 1986, z. 2.

Sułowski Z., Początki Kościoła polskiego, w: Kościół w Polsce, Kraków 1966.

Sweeney J. R., Gregory VII, the Reform Program, and the Hungarian Church at the end of the Eleventh Century, Studi gregoriani per la storia della Libertas Ecclesiae 14, 1991.

Swoboda W., Papiestwo a Słowianie, w: Słownik starożytności słowiańskich, t. VIII, Wrocław 1991. 
Szczur S., Kościół krakowski a Stolica Apostolska we wczesnym średniowieczu, Analecta Cracoviensia 32, 2000.

Szuromi Sz. A., Les Synodes d' Esztergom et les collectiones canonique en Hongrie au XII ${ }^{\mathrm{e}}$ siècle, w: Medieval Canon Law Collections and European Ius Commune (Középkori kánonjogi gyüjtemények és az európai ius commune), Budapest 2006.

Szymański J., Krakowski epizod biskupa Roberta, w: Cultus et cognitio. Studia z dziejów średniowiecznej kultury, Warszawa 1976.

Szymański J., Krakowski rękopis reguły akwizgrańskiej z roku około 1103, Studia Źródłoznawcze 11, 1966.

Szymański J., W sprawie genezy rocznikarstwa śląskiego, Studia Źródłoznawcze 22, 1977.

Szymański J., Wstęp, w: Monumenta Poloniae historica, series nova, t. X/2, Warszawa 1974.

Tazbirowa J., Początki biskupstwa na Kujawach, Przegląd Historyczny 53, 1962.

The Monuments of the Dean and Chapter of Canterbury, w: Historical Manuscript Commission. Report of Manuscript in Various Collections, wyd. R. S. Poole, London 1901.

Tillmann H., Die päpstlichen Legaten in England bis zur Beendung der Legation Gualas (1218), Bonn 1926.

Vetulani A., Krakowska biblioteka katedralna w świetle swego inwentarza z roku 1110, Slavia Antiqua 4, 1953.

Vita sancti Anselmi auctore Eadmero, w: Patrologiae Latinae cursus completus, t. 158, Parisiis 1863.

Wędzki A., Czasław, w: Słownik starożytności słowiańskich, t. I, Wrocław 1961.

Weiß S., Die Urkunden der päpstlichen Legaten von Leo IX. bis Coelestin III. (1049-1198), Köln 1995.

Wiszewski P., Domus Bolezlai. W poszukiwaniu tradycji dynastycznej Piastów (do około 1138 roku), Wrocław 2008.

Wojciechowski T., Szkice historyczne XI wieku, wyd. 4, Warszawa 1970.

Wójcik W. ks., Prawo celibatu w Polsce średniowiecznej, Roczniki Teologiczno-Kanonistyczne $5,1958$.

Závodszky L., Szent István, Szent Lászlo és Kálmán korabeli törvények és zsinati határozatok forrásai, Budapest 1904.

Zbiór dokumentów średniowiecznych do objaśniania prawa polskiego ziemskiego służących, wyd. F. Piekosiński, Kraków 1897.

Zerbi P., La „Significasti” di Pasquale II è diretta a un arcivescovo di Spalato? Riflessioni e ipotesti, w: tegoż, „Ecclesia in hoc mundo posita”. Studi di storia e di storiografia medioevale, Milano 1993.

Zey C., Alberzoni M. P., Legati papali e delegati papali (secoli XII-XIII). Stato della ricerca e questioni aperte, w: Legati e delegati papali. Profili, ambiti d'azione e tipologie di intervento nei secoli XII-XIII, Milano 2012.

Zey C., Die Augen des Papstes. Zu Eigenschaften und Vollmachten päpstlicher Legaten, w: Römisches Zentrum und kirchliche Peripherie. Das universale Papsttum als Bezugspunkt der Kirchen von den Reformpäpsten bis zu Innocenz III., Berlin 2008.

Zey C., Handlungsspielräume - Handlungsinitiativen. Aspekte der päpstlichen Legatenpolitik im 12. Jahrhundert, w: Zentrum und Netzwerk. Kirchliche Kommunikation und Raumstrukturen im Mittelalter, Berlin 2008.

Ziese J., Wibert von Ravenna. Der Gegenpapst Clemens III (1084-1100), Stuttgart 1982 (Päpste und Papsttum 20).

Zingg R., Die Briefsammlungen der Erzbischöfe von Canterbury, 1070-1170. Kommunikation und Argumentation im Zeitalter der Investiturkonflikte, Köln 2012.

Żebrowski T., Kościół X-XIII wiek, w: Dzieje Mazowsza do 1526, Warszawa 1994. 


\section{Die Legation Gualos von Beauvais in Polen im Jahre 1103}

\section{Zusammenfassung}

Eines der wichtigsten Ereignisse in der Geschichte des polnischen Staates und der Kirche im ersten Jahrzehnt des 12. Jahrhunderts war der Besuch des päpstlichen Legaten Gualo, des damaligen Elekten von Beauvais und nachmaligen Bischofs von Paris, in Polen. Die Forschungsdiskussion über diese Legation dauert seit Jahrzehnten ununterbrochen an, dennoch ist darüber weiterhin nur wenig bekannt. Dies liegt selbstverständlich an der Dürftigkeit der Quellen, die sich gewissermaßen auf das zwei Sätze umfassende Zeugnis des Gallus Anonymus und die Einträge in einigen polnischen Annalen beschränken. Wir erfahren daraus lediglich, daß der Legat die Unterstützung Boleslaus' Schiefmunds für seine Tätigkeit erfuhr und eine Synode einberief, auf der zwei Bischöfe ihres Amtes enthoben wurden. Unter Berücksichtigung zahlreicher Quellen aus den Nachbarstaaten und aus Westeuropa bemühen wir uns im vorliegenden Beitrag, vier mit der Legation verbundene Zweifel zu zerstreuen. Zunächst fragen wir, ob die Legation im Jahre 1103, 1104 oder 1105 stattfand, und sprechen uns schließlich für das Jahr 1103 aus. Danach überlegen wir, welche beiden abgesetzten Bischöfe die Quellen meinen könnten, und gelangen zu dem Ergebnis, daß es sich bei ihnen um die Bischöfe von Posen und Płock handeln müßte, auch wenn man über sie nichts Näheres weiß. An dieser Stelle unserer Überlegungen setzten wir uns kritisch mit der traditionellen Meinung auseinander, nach der es sich bei einem der abgesetzten Oberhirten um den Krakauer Bischof Caslaus gehandelt haben soll. Im dritten Punkt unserer Darstellung versuchen wir, die wahrscheinlichsten Motive für Gualos Vorgehen zu ergründen und kommen zu dem Schluß, daß es sich dabei um rechtliche Gründe gehandelt haben müßte. Demnach dürften die beiden Bischöfe wahrscheinlich von einem Metropoliten geweiht worden sein, der kein Pallium vorweisen konnte, so daß ihre Weihe für ungültig erklärt worden sein dürfte. Im letzten Abschnitt unseres Beitrages stimmen wir den neuesten Forschungen P. Nowaks zu, denen zufolge Gualo kein Exemplar der Tripartita nach Polen mitgebracht habe und die beiden polnischen, aus dem 12. Jahrhundert stammenden Handschriften dieses Werkes keinen gemeinsamen Archetypen besitzen.

Übersetzt von Waldemar Könighaus

\section{The legation of Gualo of Beauvais in Poland in 1103}

\section{Abstract}

The paper consists of its author's reflections on the visit to Poland made by the papal legate Gualo, bishop-elect of the diocese of Beauvais, and later diocesan bishop of Paris. The core of the discussion is an attempt to find answers to four key controversies related to this question, namely: a) in which year $(1103,1104$ or 1105$)$ the legation of Gualo took place, b) which two Polish bishops were removed by him, c) what may have been the most probable reasons for that decision, and d) whether in the light of recent scholarship the assertion that the legate brought to Poland a copy of Tripartita can be accepted. The text is closed with a recapitulation. 